\title{
NEPAL
}

\section{Energy Infrastructure Sector Assessment}

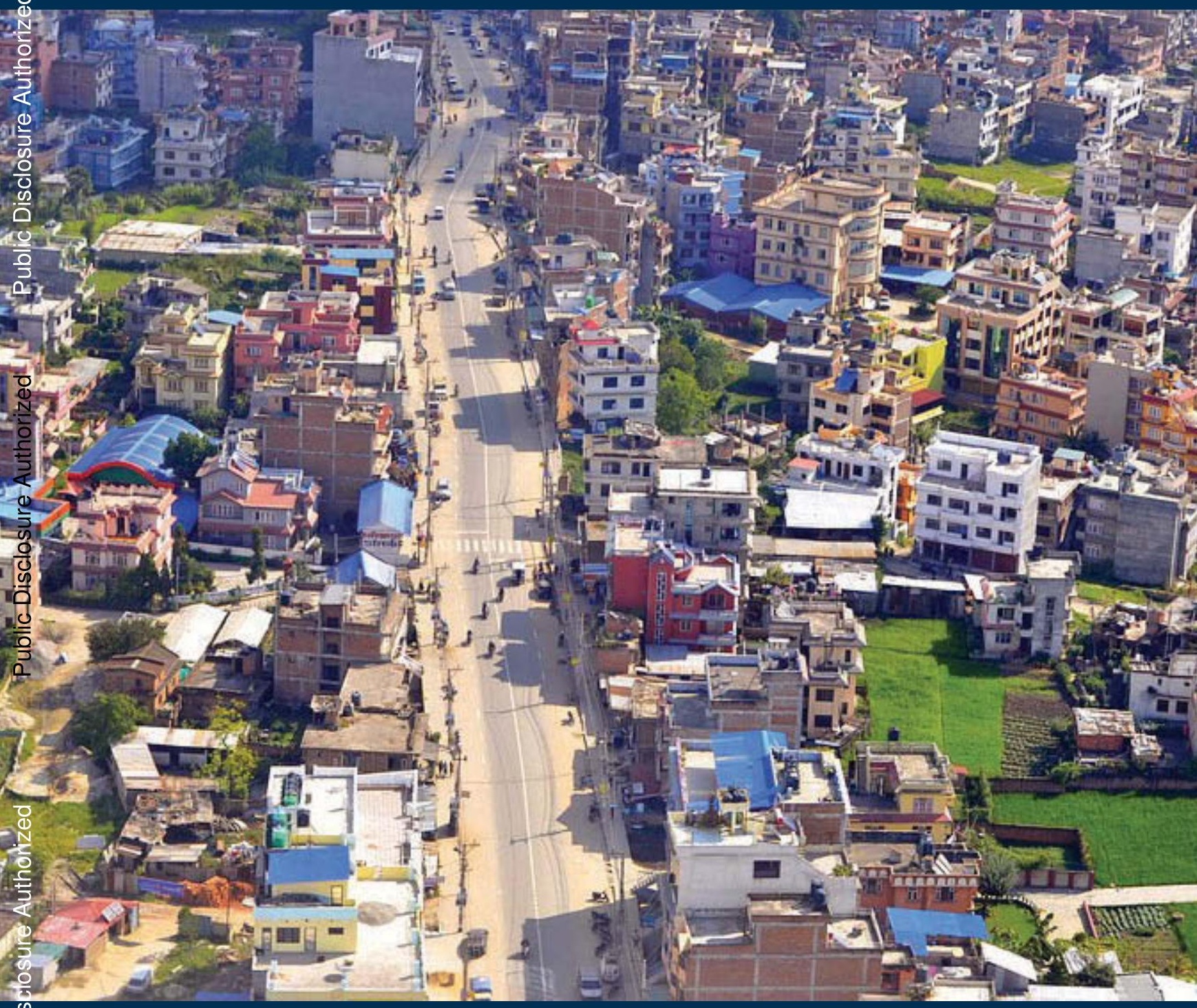




\section{NEPAL \\ Energy Infrastructure Sector Assessment}

April 2019 



\section{Contents}

Acknowledgments. . . . . . . . . . . . . . . . . . . . . . . . . . . .

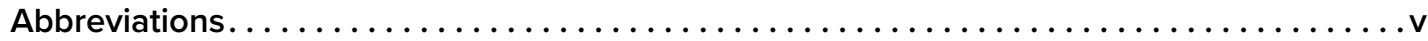

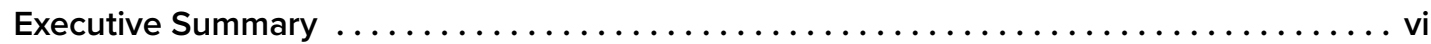

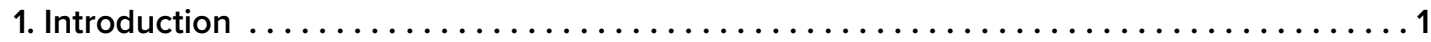

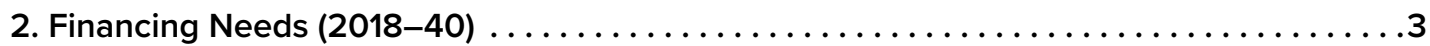

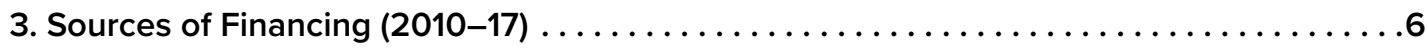

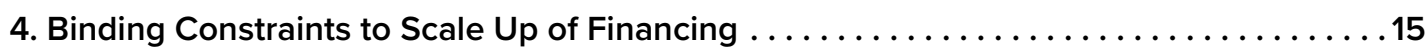

4.1 Constraints Affecting Capacity and the Enabling Environment $\ldots \ldots \ldots \ldots \ldots 15$

4.2 Constraints Affecting Financial Viability $\ldots \ldots \ldots \ldots \ldots \ldots \ldots \ldots \ldots \ldots \ldots \ldots \ldots \ldots \ldots \ldots$

4.3 Constraints Affecting the Availability of Long-Term Financing . . . . . . . . 18

4.4 Constraints Affecting Foreign Investments $\ldots \ldots \ldots \ldots \ldots \ldots \ldots \ldots \ldots \ldots \ldots \ldots \ldots$

5. Roadmap to Unlock New Sources of Finance $\ldots \ldots \ldots \ldots \ldots \ldots \ldots \ldots \ldots \ldots \ldots \ldots$

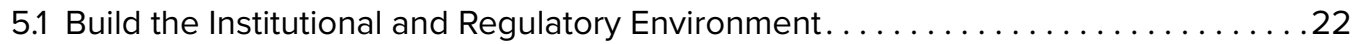

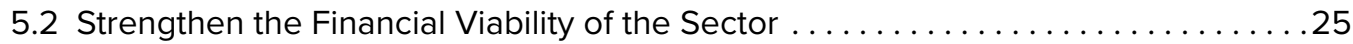

5.3 Increase the Availability of Long-Term Finance................... 26

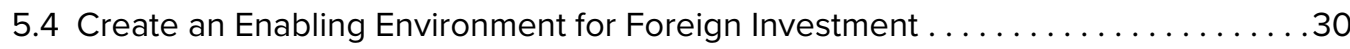

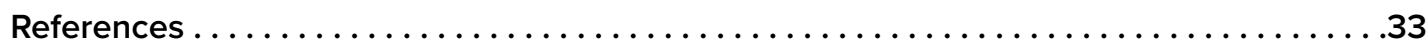

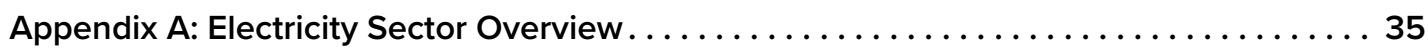

Appendix B: Financial Analysis of Nepal Electricity Authority $\ldots \ldots \ldots \ldots \ldots \ldots \ldots \ldots 2$

Appendix C: Investment Requirements under the Business as Usual Scenario . . . . . . 49 


\section{Acknowledgments}

The report was prepared for the Nepal Infrastructure Sector Assessment Program (InfraSAP) by a team led by Bipul Singh (Senior Energy Economist) comprising Lopa Shah (Senior Investment Officer, IFC), Xiaoping Wang (Senior Energy Specialist), and Yuge Ma (Young Professional), under the guidance of Demetrios Papathanasiou (Practice Manager GEE06).

Key contributions were provided by Ajay Gundecha, Consultant; Ashim Nepal, Financial Sector Specialist; Bhola Shrestha, Consultant; Nuru Lama, Principal Investment Officer; Pankaj Sinha, Senior Investment Officer; Pinki Chaudhuri, Consultant; Pravin Karki, Senior Hydropower Specialist; Rabin Shrestha, Senior Energy Specialist; Rupinder Kaur Rai, Analyst; Sabin Raj Shrestha, Senior Financial Sector Specialist; Sandeep Kohli, Senior Energy Specialist; Subodh Adhikari, Senior Energy Specialist; and Santosh Pandey, Country Officer.

The team is grateful for the inputs of the task team leaders of the Nepal InfraSAP-Shyamala Shukla, Senior Specialist, Infrastructure, Public-Private Partnerships and Guarantees; and Sanjay Srivastava, Program Leader.

The following peer reviewers provided valuable comments and advice: Aijaz Ahmad, Kamal Dorabawila, Moazzam Mekan, Peter Mousley, Yogita Mumssen, Volker Treichel, and Andre Van Hoeck.

Overall guidance on the report was provided by Qimiao Fan, Country Director, Nepal, Bangladesh, and Bhutan; Faris Hadad-Zervos, Country Manager, Nepal, World Bank; Clive Harris, Head, Maximizing Finance for Development; Abha Joshi-Ghani, Senior Advisor, Infrastructure Programs and Analytics; Ranjit Lamech, Director, Energy; Sebnem Erol Madan, Manager, Financial Structuring and Public-Private Partnerships; Richard Bernard McGeorge, Lead Infrastructure Finance Specialist; Jason Z. Lu, Head, Global Infrastructure Facility; Bigyan Pradhan, Senior Operations Officer, World Bank; Jordan Schwartz, Director, Infrastructure, Public-Private Partnerships, and Guarantees (IPG); Shamsher Singh, Chief Investment Officer, International Finance Corporation (IFC); Wendy Jo Werner, Country Manager, IFC; Lubomir G. Varbanov, Manager, IFC; and Sumeet Thakur, Senior Manager, IFC.

The World Bank team thanks the Federal Ministry of Finance-specifically the Government of Nepal InfraSAP Working Group, National Planning Commission, Investment Board of Nepal, Department of Electricity Development, Nepal Electricity Authority, Ministry of Energy, Hydroelectricity Investment and Development Company Limited, and the Government of Nepal-for providing valuable support in the implementation of this project.

The team thanks Arnab Datta for technical writing and editing and Sandra Gain and Joan O'Callaghan for editing.

This report is a product of the World Bank Group. Funding for this product has been provided by the Country Management Unit, Nepal, the Public-Private Infrastructure Advisory Facility, and the IPG. 


\section{Abbreviations}

\begin{tabular}{|c|c|c|c|}
\hline $\mathrm{ACoS}$ & average cost of supply & MOF & Ministry of Finance \\
\hline \multirow{6}{*}{$\begin{array}{l}\text { ADB } \\
\text { BAU } \\
\text { capex } \\
\text { CIT } \\
\text { EGCL }\end{array}$} & Asian Development Bank & MOFEP & Ministry of Finance and \\
\hline & business as usual & & Economic Planning \\
\hline & capital expenditure & MOLJP & Ministry of Law, Justice, and \\
\hline & Citizen Investment Trust & & Parliamentary Affairs \\
\hline & Electricity Generation & MW & megawatt \\
\hline & Company Limited & NEA & Nepal Electricity Authority \\
\hline \multirow{2}{*}{$\begin{array}{l}\text { EPF } \\
\text { ERC }\end{array}$} & Employees Provident Fund & NGTCL & National Grid Transmission \\
\hline & $\begin{array}{l}\text { Electricity Regulatory } \\
\text { Commission }\end{array}$ & NPR & $\begin{array}{l}\text { Company Limited } \\
\text { Nepalese rupee }\end{array}$ \\
\hline \multirow{2}{*}{$\begin{array}{l}\text { FDI } \\
\text { FY }\end{array}$} & foreign direct investment & NPTCL & $\begin{array}{l}\text { Nepal Power Trading Company } \\
\text { Limited }\end{array}$ \\
\hline & fiscal year & NDP & Nepal Rastra Bank \\
\hline GDP & gross domestic product & & Teration and mainter \\
\hline GoN & government of Nepal & U\&IM & operation and maintenance \\
\hline \multirow{3}{*}{$\begin{array}{l}\text { GW } \\
\text { GWh } \\
\text { HIDCL }\end{array}$} & gigawatts & OI & operating income \\
\hline & gigawatt-hours & PBIT & profit before interest and taxes \\
\hline & $\begin{array}{l}\text { Hydroelectric Investment } \\
\text { Development Company Limited }\end{array}$ & PBITDA & $\begin{array}{l}\text { profit before interest, taxes, } \\
\text { depreciation, and amortization }\end{array}$ \\
\hline \multirow{2}{*}{$\begin{array}{l}\text { IBN } \\
\text { IFC }\end{array}$} & Investment Board Nepal & PBT & profit before tax \\
\hline & $\begin{array}{l}\text { International Finance } \\
\text { Corporation }\end{array}$ & PDA & $\begin{array}{l}\text { project development } \\
\text { agreement }\end{array}$ \\
\hline \multirow{2}{*}{ IIF } & Indonesia Infrastructure & PP & power purchase \\
\hline & Finance & PPA & power purchase agreement \\
\hline InfraSAP & $\begin{array}{l}\text { Infrastructure Sector } \\
\text { Assessment Program }\end{array}$ & PPI & $\begin{array}{l}\text { private participation in } \\
\text { infrastructure }\end{array}$ \\
\hline \multirow[t]{2}{*}{ IPG } & Infrastructure, Public-Private & PPP & Public-private partnership \\
\hline & Partnerships and Guarantees & PROR & peaking run-of-the-river \\
\hline IPO & initial public offering & ROR & run-of-the-river \\
\hline IPP & independent power producer & RPGCL & Rastriya Prasaran Grid \\
\hline $\mathrm{km}$ & kilometer & & Company Limited \\
\hline $\mathrm{kV}$ & kilovolt & SOE & state-owned enterprise \\
\hline kWh & kilowatt-hour & $\mathrm{T} \& \mathrm{D}$ & transmission and distribution \\
\hline
\end{tabular}




\section{Executive Summary}

The electricity sector is one of the most strategically important areas of Nepal's economy for two reasons. First, the lack of adequate electricity is a barrier to higher economic growth, and increasing access to electricity has the potential to yield significant economic dividends. Second, Nepal's vast hydropower potential creates an opportunity for the country to earn revenue by exporting power to the South Asia region. The Government of Nepal (GoN) has set an ambitious target of installing 3 gigawatts (GW) of generation capacity in three years, $5 \mathrm{GW}$ in five years, and $15 \mathrm{GW}$ in 10 years.

A twofold to fourfold increase in investments is needed to meet the projected demand in the country and use the sector's export potential. Electricity sector investments will need to accelerate substantially to an average of US\$1.3-\$2.1 billion annually between 2019 and 2040 . Nepal needs to not only efficiently use existing sources of financing, but also develop the capacity to access new sources of financing from domestic and international capital markets and investors, including institutional investors.

A scale-up in both public and private financing is needed to meet the economic potential of Nepal's electricity sector. The domestic private sector and financial sector can continue to take the lead in the development of small hydropower projects and solar and wind energy projects. There is also potential to mobilize private investments in transmission. Public sector entities and foreign investors can play a strong role, with assistance from multilateral development agencies, in structuring large hydropower projects. Public and private financing may be used for large hydropower projects; risk mitigation instruments can be applied to leverage significant commercial financing from local and international investors. Such large infrastructure provides an opportunity to also deepen local capital markets. Suggested interventions to increase financing in the electricity sector are outlined as follows:

Pillar 1: Build the sector's institutional and regulatory environment. There is a need to build the capacity of new public-sector agencies in the electricity sector and assist them in mobilizing financing, including private and commercial financing. To improve public investment management, the government is advised to establish a well-resourced central coordination mechanism, ideally in the Prime Minister's Office. To enable higher levels of private investment in the electricity sector, the government should pursue initiatives to create a level playing field for the private sector through sector restructuring and integration with the regional electricity market.

Pillar 2: Strengthen the financial viability of the sector. A sustained focus on increasing revenue, reducing system losses, and financing costs is necessary to enable the Nepal Electricity Authority (NEA) to meet its obligations and maintain robust financial health. This can be achieved through policy actions to (1) ensure cost-reflective tariffs, reduce transmission and distribution losses, and implement the NEA's financial viability plan and pursue actions to get a credit rating for the NEA; and (2) strengthen the enabling conditions for electricity trade with Nepal's neighbors by establishing the appropriate legal, regulatory, and institutional 
environment. Improved financial viability would increase the ability of electricity sector institutions to mobilize financing from the capital market.

Pillar 3: Increase the availability of long-term finance. The GoN is keen to establish broadbased ownership of the country's hydro assets through the stock market under its People's Investment in Nepal's Water Resources program. However, at present it is not possible to mobilize significant amounts of local financing, because of variable interest rates, short tenors, inefficient regulations, and low capacity. Addressing these constraints calls for a concerted effort to deepen and broaden Nepal's capital markets as an alternative channel of long-term finance. There is a need to address the capacity constraints faced by local commercial banks, enabling nonrecourse project finance, and strengthening the capacity of the Hydroelectric Investment Development Company Limited. The GoN should pursue equitization of NEA generation assets, develop a comprehensive asset-recycling framework, and create an enabling environment for asset-recycling tools.

Pillar 4: Develop an enabling environment for foreign investments. The GoN is advised to undertake targeted policy actions to increase the role of foreign investors and financiers in the sector while closely monitoring the fiscal commitments and contingent liabilities that arise from such arrangements. Priority actions are needed to establish a hedging facility to reduce foreign currency risks and help attract foreign finance for projects, establish a onestop window for obtaining all government clearances for private sector investments, ease limits on foreign currency borrowings, facilitate foreign exchange-related transactions, harmonize legal and regulatory inconsistencies and improve the legal framework for foreign direct investment, and address deficiencies in the current dollar power purchase agreement/ project development agreement. 


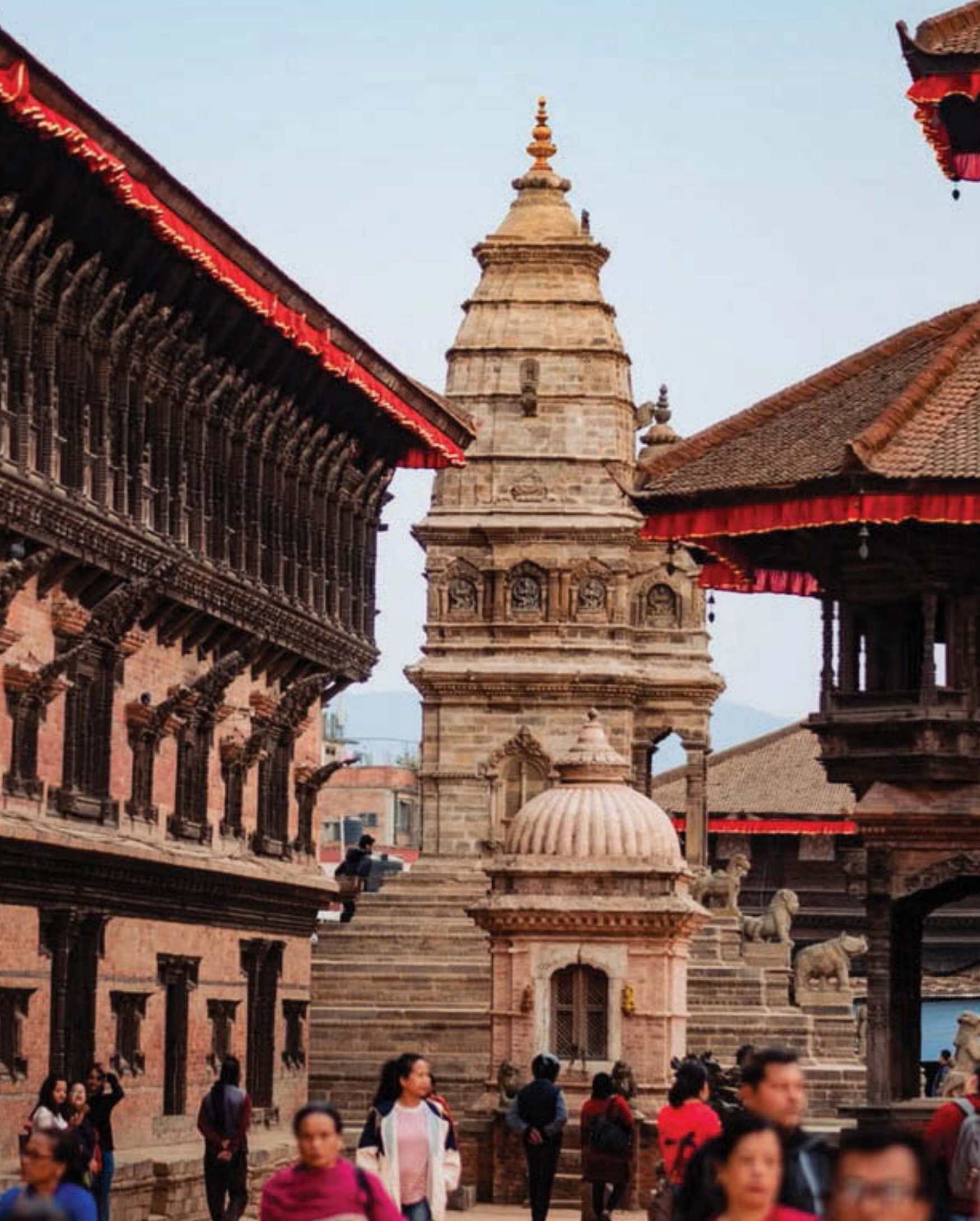




\section{Introduction}

With the conclusion of the decade long peace and constitutional process, the Government of Nepal (GoN) is keen to accelerate economic growth to become a middle-income country by 2030. While Nepal has the savings necessary for high growth rates, it has been unable to mobilize them fully for investment. Over the past 16 years, gross national savings have averaged 34 percent of gross domestic product (GDP) and have exceeded capital formation in each year, which has averaged 22 percent of GDP. Nepal's public investment has averaged 4 percent of GDP, which is below average among both South Asian and low-income countries. There is chronic underspending of the capital budget, with spending averaging about 70-80 percent over the past 5 years (World Bank 2017). Furthermore, the efficiency of this investment is very low.

The electricity sector is one of the most strategic areas of Nepal's economy for two reasons. First, the lack of adequate electricity is a barrier to higher economic growth. The Nepalese consume, on average, just a twentieth of the global average and a fifth of the South Asian average. Load shedding imposed economic costs of up to US\$1.6 billion per year during 2008-16 (Timilsina et al. 2017). There is hence an opportunity to achieve a large economic payoff by increasing electricity supply. Second, Nepal has an opportunity to earn revenue by exporting valuable hydropower in the South Asia region. Recognizing this, the government has set an ambitious target of installing 3 gigawatts (GW) of generation capacity in 3 years, 5 GW in 5 years, and 15 GW in 10 years (Ministry of Energy, Water Resources and Irrigation 2018). Nepal is pursuing reforms to increase the capacity of public sector institutions and improve the investment climate in the sector.

Nepal has recovered from the severe electricity crisis that adversely affected the country between 2008 and 2016. Nepal's electricity imports from India have increased fourfold since 2010 and now comprise more than a third of the electricity consumption in the country (see Appendix 1 for an Electricity Sector Overview). Combined with more efficient management of existing generation resources and reduced transmission and distribution (T\&D) losses, the NEA has resolved load shedding. The Nepal Electricity Authority (NEA) has also achieved progress in improving its financial performance and creating a robust pipeline of public and private sector projects, by signing power purchase agreements (PPAs) for more than $4 \mathrm{GW}$ of new projects. However, questions remain on how many projects from this $4 \mathrm{GW}$ of pipeline are progressing and how they will be financed through local sources. In any case, Nepal would need to increase investment in the electricity sector beyond this pipeline, to realize the government's ambitions for the sector and achieve higher economic growth.

The seasonality of Nepal's hydro sector offers win-win opportunities for Nepal and its neighbors but requires substantial investments and regulatory and institutional reforms. Once the extensive pipeline of run-of-the-river (ROR) projects comes online by 2020, Nepal could have a surplus in the wet season but a shortage in the dry season. Electricity trade with its neighbors would improve the efficiency and reliability of Nepal's electricity system in a cost-effective way. Furthermore, Nepal could benefit from the growing market for hydropower to provide ancillary services to balance variable renewable energy resources, such as solar and wind in India. 
Achieving the full economic potential of the electricity sector will require a paradigm shift in the way Nepal approaches electricity sector financing. Nepal has historically relied on a mix of public and private financing in the electricity sector. The country's installed generation capacity is now almost equally divided between the NEA and independent power producers (IPPs) - the latter mostly in the form of small hydropower projects developed with local investments. However, a twofold to fourfold increase in investment is needed to meet the projected demand in the country and maximize the sector's export potential. Toward this end, Nepal must not only efficiently use existing sources of financing, but also develop the capacity to access new sources of financing from domestic and international capital markets and investors, including institutional investors.

Nepal will need to deploy a wide range of public-private partnership (PPP) models in the electricity sector. In general, small hydropower projects and most solar and wind energy projects have a risk profile and relatively short construction periods that are conducive to private sector investment and commercial financing. However, Nepal's domestic private sector does not yet have the capacity to mobilize large amounts of long-term financing and appraise and manage the significant technical, hydrological, and environmental risks of large hydropower projects. Public sector entities and foreign investors can play a strong role, with assistance from multilateral development agencies, in structuring large hydropower projects. Public and private financing may be used for large hydropower projects; risk mitigation instruments can be applied to leverage significant commercial financing from local and international investors. Such large infrastructure provides an opportunity to also deepen local capital markets (see, for instance, box 1 on the Upper Tamakoshi project and box 3 on international experience with large hydropower projects).

An integrated regional electricity market will open opportunities for commercial debt and equity financing of Nepal's large hydropower projects. Since there would be greater potential to match the currency of revenues and liabilities in such projects, this would help mitigate the sector's exposure to foreign currency fluctuations. Nepal has already awarded some larger hydropower projects to foreign investors (private and state owned) and is accumulating experience through these investments. Several large hydropower projects have been constructed with the private sector globally and can provide valuable lessons on how foreign investment and financing can flow into the sector sustainably, while managing associated risks and contingent liabilities as compared with direct liabilities in public-sector projects (see box 3 on private sector experience with large hydropower projects).

The purpose of this report is to identify how to maximize finance available to Nepal in the electricity sector. This report identifies financing needs and constraints for the electricity sector in the short to medium term and outlines a road map for overcoming these constraints and seizing opportunities to gradually achieve a sectoral transformation. The report forms part of the World Bank Group's Infrastructure Sector Assessment Program (Infra-SAP). 


\section{Financing Needs (2018-40)}

Despite moderate economic growth, electricity demand in Nepal has risen rapidly. Since 1995 , the compound annual growth rate of demand has been 8 percent, resulting in a doubling of electricity consumption every eight years. The government is targeting an acceleration of average economic growth to 7.2 percent during 2018-40, from 4.5 percent during 1998-2018. Under the reference case scenario, the government expects electricity demand to increase at a compound annual growth rate of 12.0 percent, implying a doubling of electricity consumption every six years. Under the business as usual (BAU) scenario, economic growth and electricity demand are expected to increase at historic rates of 4.5 and 10.0 percent, respectively (figure 1).

FIGURE 1: Actual and Projected Electricity Demand (GWh)

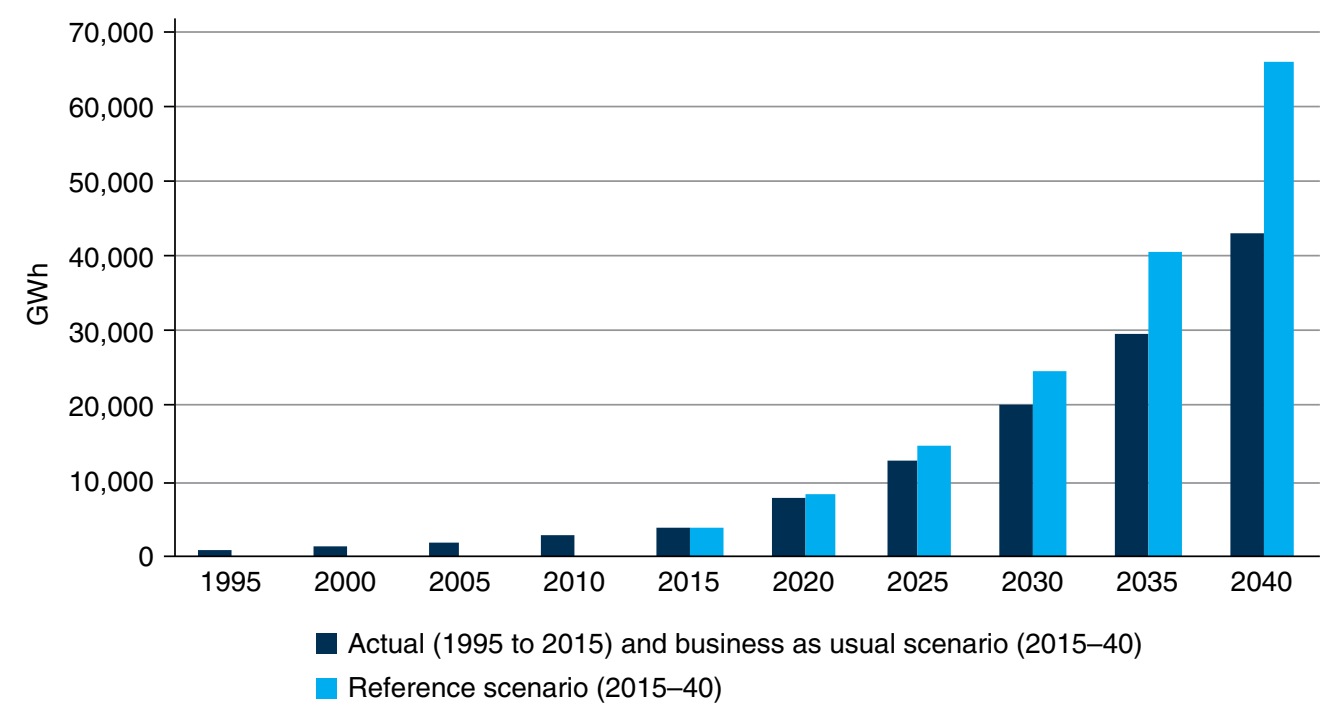

Source: Nepal Electricity Authority and Water and Energy Commission Secretariat. Note: GWh = gigawatt hours.

From 2010 to 2017, Nepal's electricity sector achieved investments of US\$527 million per year on average. More than 70 percent of this investment was concentrated in the power generation segment, and almost all of this went to hydropower projects. Two-thirds of the investment in generation was undertaken by NEA subsidiary companies, followed by local IPPs and the NEA. Although it is significant, the sum falls short of the required annual investments for 2018-40. 
To keep pace with demand, electricity sector investments will need to accelerate substantially to an average of US\$1.3-\$2.1 billion annually between 2018 and $2040 .{ }^{1}$ The total investment need in the power sector for the forecast period of 2018-40 is estimated at US $\$ 29-\$ 46$ billion. This includes total investments of more than US $\$ 16$ billion in T\&D and US $\$ 2$ billion in solar and wind energy during 2018-40 (table 1). The estimated annual need for US\$1.3-\$2.1 billion is two to four times higher than achievements in the recent past. Although ROR and peaking run-of-the-river (PROR) hydro continue to dominate generation investments (60 percent of the generation $\mathrm{mix}$ ), there is increased prioritization of storage hydropower plants (30 percent of the generation mix) and new renewable energy (10 percent of the generation mix).

Moreover, incremental investments of US\$0.5-\$1.0 billion may be required annually in large, export-oriented hydropower projects. The takeoff of export-oriented projects will depend on the underlying economics of these projects, as well as the development of an effective institutional and regulatory framework for electricity trade.

TABLE 1: Historical Investments (2010-17) and Projected Investment Needs, 2018-40

\begin{tabular}{|c|c|c|c|c|c|c|}
\hline \multirow[b]{3}{*}{ Type of investment } & \multicolumn{5}{|c|}{ Average annual investments (US\$ million, 2018 prices) } & \multirow{3}{*}{$\begin{array}{c}\text { Total investment } \\
\text { financing needs } \\
\text { (US\$ million) }\end{array}$} \\
\hline & $\begin{array}{c}\text { Historical } \\
\text { investments }\end{array}$ & \multicolumn{4}{|c|}{ Forecast periods-reference scenario } & \\
\hline & 2010-17 & $2018-25$ & 2026-30 & 2031-35 & $2036-40$ & \\
\hline Hydro storage & - & 393 & 404 & 631 & 1,017 & 13,012 \\
\hline Hydro (ROR+PROR) ${ }^{2}$ & 372 & 301 & 485 & 757 & 1,221 & 14,424 \\
\hline Solar/wind & - & 69 & 67 & 90 & 148 & 1,945 \\
\hline T\&D & 156 & 414 & 539 & 842 & 1,356 & 16,587 \\
\hline Total & 527 & 1,177 & 1,487 & 2,320 & 3,739 & 45,968 \\
\hline Total (\% of GDP) & 2.1 & 2.7 & 2.4 & 2.6 & 3.0 & $2.0-3.0$ \\
\hline
\end{tabular}

Sources: Historical investments based on private participation in infrastructure (PPI) Database 2018 and NEA Annual Report 2018. Projected investments are World Bank estimates based on the Water and Energy Commission Secretariat's 2017 reference case electricity demand projections.

Note: $-=$ not available; GDP = gross domestic product; PROR = peaking run-of-the-river; ROR = run-of-the-river; $T \& D=$ transmission and distribution.

The NEA will continue to play an important role and be responsible for about a third of the total sector investment requirements until 2030. More than 95 percent of the NEA capital expenditure is expected in the T\&D network. The NEA will also continue to make equity investments in subsidiary companies to develop generation projects. About half of the additional generation capacity between 2018 and 2030 is expected to be developed by NEA subsidiary companies. From 2019 to 2025, NEA debt financing requirements to meet capital expenditure (capex) needs range between US $\$ 250$ million and US $\$ 500$ million annually (table 2) (NEA 2018a). However, by

\footnotetext{
${ }_{1}^{1}$ The investment amounts of US $\$ 1.3$ billion and US $\$ 2.1$ billion correspond to the government's business as usual and reference case scenario demand projections, respectively. The breakdown of investment in the reference scenario is provided in table 1, while the breakdown of the investment in the BAU scenario is given in Appendix C.

${ }^{2}$ Run-of-river hydroelectricity is the type of hydroelectric generation plant whereby little or no water storage is provided. Peaking run-of-the-river hydropower plants are defined by the NEA as hydropower plants that can provide at least four hours of electricity in the peak hours.
} 
removing constraints to greater private sector participation-in the ownership, operations, and financing of power projects-the government can leverage its public-sector resources by using a range of PPP models.

TABLE 2: NEA Debt Financing Requirement, 2019-25

\begin{tabular}{|c|c|c|c|c|c|c|c|}
\hline & \multicolumn{7}{|c|}{ US\$ million } \\
\cline { 2 - 9 } & 2019 & 2020 & 2021 & 2022 & $\mathbf{2 0 2 3}$ & $\mathbf{2 0 2 4}$ & 2025 \\
\hline
\end{tabular}

Source: NEA Financial Viability Action Plan 2018. 


\section{Sources of Financing (2010-17)}

The electricity sector relied on state financing for more than two-thirds of its investment program between 2010 and 2017. This financing was almost equally divided between the NEA and NEA subsidiary companies. Between 2010 and 2017, the NEA's entire capital expenditure, amounting to US $\$ 1.4$ billion, was financed by the government. Four-fifths of this investment was estimated to have gone into T\&D, and the remaining fifth into generation. About half of the NEA's capital expenditure and investment was loaned to the NEA by the government, which had borrowed it from a variety of development partners. The remaining half was passed to the NEA as government equity. The NEA's long-term debt obligations to the government increased from US $\$ 0.5$ billion to US $\$ 1.1$ billion, and the government's equity contributions to the NEA increased from US\$358 million to US\$961 million in this period (NEA 2018a).

The GoN is using NEA subsidiary companies to develop large hydropower projects, by leveraging financing from institutional investors and state-owned enterprises. Projects led by NEA subsidiary companies invested US $\$ 1.5$ billion and accounted for more than a third of the sector's investments from 2010 to 2017. The NEA's equity investment in its six subsidiary companies increased by US $\$ 232$ million between 2010 and 2017. NEA subsidiary companies mobilized an additional US $\$ 1.1$ billion of equity and debt financing from institutional and public sector investors in addition to initial public offerings (IPOs) on the stock market during this period. More than 800 megawatts (MW) of generation projects developed by NEA subsidiary companies reached financial closure between 2010 and 2017 and are currently under construction. The 456-MW Upper Tamakoshi Hydropower Project, Nepal's largest hydropower project to date, accounts for half of this capacity. This project is being developed with debt and equity investments from the Employees Provident Fund, Citizens Investment Fund, and Rashtriya Beema Sansthan (box 1). NEA subsidiary companies have raised or have provisions to raise at least 25 percent of the equity financing from local communities, employees of sponsor agencies, and the public through IPOs.

The domestic private sector, alone and in joint venture with foreign partners, is an active participant in the development of hydropower projects that are less than $100 \mathrm{MW}$ (figure 2). IPPs contributed about a fifth of the total electricity sector investments between 2010 and 2017. They invested more than US $\$ 700$ million in $406 \mathrm{MW}$ of hydropower generation during 2010-18. About a third of this was equity investments, and the remaining two-thirds was debt financing from local and foreign financial institutions and bilateral and multilateral donors. The NEA offers differentiated PPA rates ranging from US $\$ 0.04$ to US $\$ 0.08$ for ROR projects of less than 100 MW capacity in the dry and wet seasons, respectively. The NEA has signed local currency PPAs for more than 2,000 MW of new capacity with the domestic private sector. Most of these projects are seeking financial closure or are in the early stages of construction. 


\section{Box 1: Upper Tamakoshi Hydropower Project}

The Upper Tamakoshi Hydroelectric Project is a 456-megawatt peaking run-of-the-river hydroelectric project on the Tamakoshi River, near the Nepal-Tibet border. The project is being developed by Upper Tamakoshi Hydropower Limited, a subsidiary of the Nepal Electricity Authority (NEA). The majority shares ( 51 percent) of the company are held by four public entities: NEA (41 percent), Nepal Telecom ( 8 percent), Citizens Investment Fund (3 percent), and Rashtriya Beema Sansthan (3 percent). The remaining shares (49 percent) were issued through initial public offerings to Employees Provident Fund contributors, employees of Upper Tamakoshi Hydropower Limited, the NEA, lending institutions, local communities, and the public. The debt is provided by Employees Provident Fund, Nepal Telecomm, Citizens Investment Fund, Rashtriya Beema Sansthan, and the Government of Nepal.

The project has run into significant cost and time overruns as a result of disruptions caused by the 2015 earthquake, the subsequent blockade at the Indian border, and depreciation of the Nepalese currency. The project cost was initially estimated to be US $\$ 305$ million, but it is now expected to reach more than US $\$ 430$ million (US\$565 million including interest during construction). Nevertheless, the project continues to be one of the lowest-cost developments in the country in US $\$ /$ megawatt terms. The commercial operation date of the first four units of the project has been delayed until after December 2019.

Source: Upper Tamakoshi Hydropower Limited Annual Report 2018.

FIGURE 2: Electricity Sector Investments in Nepal with Private Sector Participation (US\$ million)

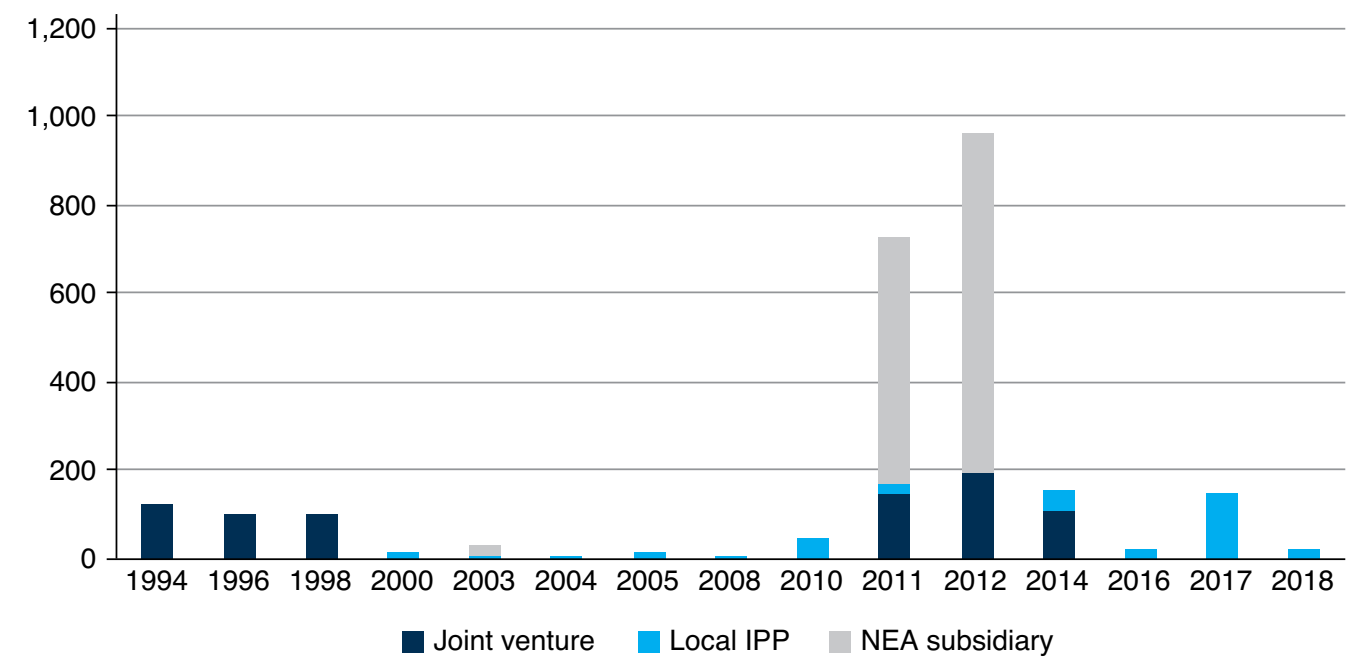

Source: PPI Database 2018.

Note: IPP = independent power producer.

Foreign investment in the electricity sector was limited between 2010 and 2017, all of which was in the form of a joint venture with local companies, accounting for approximately a tenth of the sector investments. Although the first hydropower project in Nepal was built in 1911, until 2000 state-owned utilities had added less than $280 \mathrm{MW}$ of total cumulative generation capacity in the country; however in 2002 the NEA completed the country's largest project, plant Kali Gandaki (144 MW), with Asian Development Bank (ADB) financing. Nepal's first two IPPs, the Himal Khimti Hydropower Project and Upper Bhotekoshi Hydropower Project, 
were developed by foreign investors in the late 1990s with dollar-denominated PPAs, and provided an additional 86 MW by 2001. These two IPPs not only increased the generation capacity by 30 percent within a few years in a country with significant generation capacity deficits, but also helped to promote an alternative way to build generation and developed significant domestic technical capacity outside the NEA. The government's decision not to allow increases in the electricity tariffs throughout 2001-12, combined with increasing payment obligations in local currency terms under these two dollar-denominated PPAs, contributed to a continuous decline of the NEA's financial condition. In this context, the NEA decided to sign only a few partly dollardenominated PPAs between 2000 and 2016. In 2017, under newly adopted PPA guidelines, the NEA signed two new partly dollar-denominated PPAs. The level of currency exposure in these PPAs is not likely to be adequate to attract foreign investment in the sector going forward (see box 2 on current dollar-denominated PPAs).

\section{Box 2: Current Dollar-Denominated PPA and Foreign Exchange Risk Hedging Mechanisms}

Current dollar-denominated power purchase agreements (PPAs). In 2017, the Nepal Electricity Authority (NEA) adopted new guidelines on foreign currency-denominated PPAs and subsequently signed partly dollar-denominated PPAs with two new projects: the 216-megawatt (MW) Upper Trishuli Project and the 120-MW Rasuwa-Bhotekoshi Hydropower Project. Under these new dollar-denominated PPAs, in addition to the coverage of the debt financing being limited to the first 10 years of operation and the portion of foreign debt financing, the developers/shareholders' equity investments are fully exposed to currency devaluation risk. Furthermore, as currently structured, the terms of the recent-dollar PPAs require equity investors to share one-third of the NEA's exposure to limited dollar purchase obligations by making additional financial contributions to a hedging mechanism or to foreign exchange risk exposure of the NEA. Dollar-denominated PPAs with this risk allocation and level of exposure for the developers have not been seen elsewhere. The current risk allocation is not likely to be adequate to attract investment by sponsors in foreign currency. Nevertheless, compared with the sector's trajectory over the past 15 years, the structure is progressing in the right direction.

Foreign exchange risk-hedging mechanisms. The Government of Nepal is keen to establish a hedging mechanism for better management of foreign exchange risks in the sector. One current proposal where foreign financiers would lend to Nepal Rastra Bank, which would then onlend to the beneficiary projects through a commercial bank, has several structural flaws and cannot be implemented. Another concept that is currently under discussion-a hedging facility (or "hedge fund") approach, in which developers/ lenders are also required to participate-is complex and has not been observed in power sectors in other countries.

Global experience. Global experience has shown that as countries are able to establish contractual structures to attract foreign direct investment, the developers are willing to take an increasingly greater proportion of currency devaluation risk on their equity investment. Foreign exchange risk management of the remaining investment-whether through a pass-through to the end consumer or a government subsidy-is often managed at the sector/country level, rather than at each individual project level (except in countries where long-term, cross-currency swap markets exist).

\section{The flow of private investment to transmission, distribution, and solar and wind genera-} tion was limited, but it is likely to increase. The government is keen to attract private investment to these areas and is gradually putting in place a framework to attract investments. The NEA has established a feed-in tariff of US $\$ 0.063$ /kilowatt-hour for solar energy and has issued a net metering policy for grid-connected rooftop solar. The NEA is also providing viability gap funding to solar projects under an ADB project. In transmission, the government used PPP arrangements 
to build the Dhalkebar-Muzzafarpur interconnection between India and Nepal. Going forward, the government would like to use build-and-transfer and engineering procurement construction finance arrangements to develop transmission infrastructure in the country.

After years of delay, Nepal finally broke ground on its first export-oriented hydropower project, with US\$1.1 billion in Indian investment. The 900-MW Arun 3 hydropower project, developed by state-owned Sutlej Jal Vidyut Nigam Limited with the backing of the Indian government, has reached financial closure and is under construction. The US $\$ 1.1$ billion project has a 30 percent equity contribution from Sutlej Jal Vidyut Nigam Limited. Indian and Nepalese commercial banks are providing 60 and 10 percent of the debt financing, respectively. Under the terms of the agreement of the project, Nepal will receive 22 percent of the electricity generated by the project as free power. Sutlej Jal Vidyut Nigam Limited will hand over the project to Nepal after 25 years. Although the project has faced many challenges, this is an important milestone and achievement for the expansion of the sector in Nepal and the region. At a high level, this model has key features that can be replicated successfully to facilitate other such developers. The government has also signed a project development agreement (PDA) for the development of the 950-MW Upper Karnali project with India's GMR Group, which is seeking to reach a PPA with Bangladesh.

Domestic commercial banks have provided local currency debt to projects led by the domestic private sector. Nepal's central bank requires the country's banks to lend at least 5 percent of their loan portfolio to hydropower (Nepal Rastra Bank 2019a). Yet, only about 4 percent of their loan portfolios, or US\$784 million, was channeled to the hydropower sector as of FY2018, 3 indicating some upside potential in the domestic debt market (table 3). However, the willingness and ability of local financial institutions to finance hydropower projects are limited. Local banks are constrained in financing long-term hydro projects with their mostly short-term deposits. Moreover, local financial institutions perceive hydropower to be riskier than other sectors. Banks have a small capital base, which limits lending to individual projects (USAID 2016). Currently, given prudential norms, including the single-borrower limit, local banks are unable to finance projects above US $\$ 40$ million on their own. ${ }^{4}$

Nepal's institutional investors have shown a growing appetite for hydropower investments. Their exposure to hydropower investments stood at about US $\$ 300$ million as of FY2017, or about 8 percent of the investments in hydropower during this period. Institutional investors have provided debt and equity financing to hydropower projects developed by NEA subsidiary companies. The Employees Provident Fund, which manages the pensions of government and army staff, is the most prominent of these investors, followed by Citizens Investment Fund and Rashtriya Beema Sansthan. Given that the combined asset size of the local institutional investors is more than 15 percent of GDP (US $\$ 4$ billion), there is potential to mobilize higher amounts of financing from Nepal's institutional investors by addressing regulatory and institutional barriers.

Nepal's capital market had a limited role in mobilizing sector investments during this period, although it could become an important source of funds. The government is keen to establish broad-based ownership of the country's hydro assets through the stock market

\footnotetext{
${ }^{3}$ Since some banks meet their hydropower lending requirements through short-term import letters of credit, not all of this is long-term loans for hydropower projects.

${ }^{4}$ The single-borrower limit of 50 percent of the banks' equity capital constrains lending from many of the banks and necessitates lending from a consortium of banks for projects costing more than US $\$ 40$ million.
} 
TABLE 3: Sources of Financing in the Electricity Sector (US\$ million)

\begin{tabular}{|c|c|c|c|c|c|}
\hline Institution & Instrument & Benchmark fund & $\begin{array}{c}\text { Hydro } \\
\text { financing }\end{array}$ & Share (\%) & Comments \\
\hline Commercial banks & Debt & 21,717 & 784 & 4 & $\begin{array}{l}\text { FY2019 monetary policy requires } \\
5 \% \text { of total loan portfolio of } \\
\text { commercial banks to be in } \\
\text { hydropower. } \\
\text { If a PPA has been signed, banks } \\
\text { can invest up to } 50 \% \text { of their } \\
\text { core capital in a single project; } \\
25 \% \text { of core capital otherwise. }\end{array}$ \\
\hline $\begin{array}{l}\text { Insurance } \\
\text { companies }\end{array}$ & $\begin{array}{l}\text { Equity \& } \\
\text { debt }\end{array}$ & 1,643 & 20 & 1 & $\begin{array}{l}\text { Insurance companies can } \\
\text { have up to } 5 \% \text { of their total } \\
\text { investments in hydropower } \\
\text { projects as share capital. }\end{array}$ \\
\hline $\begin{array}{l}\text { Employee Provident } \\
\text { Fund }\end{array}$ & $\begin{array}{l}\text { Equity \& } \\
\text { debt }\end{array}$ & 1,070 & 230 & 21.5 & $\begin{array}{l}\text { Investment up to a maximum } \\
\text { limit of } 25 \% \text { of issued } \\
\text { debentures. } \\
\text { Provides loans to companies } \\
\text { against guarantees of banks or } \\
\text { financial institutions. } \\
\text { Investment in any area against } \\
\text { securities or guarantees and } \\
\text { after obtaining the government's } \\
\text { approval. }\end{array}$ \\
\hline $\begin{array}{l}\text { Citizen Investment } \\
\text { Trust }\end{array}$ & $\begin{array}{c}\text { Equity \& } \\
\text { debt }\end{array}$ & 920 & 28 & 3 & $\begin{array}{l}\text { Invest in securities up to } 20 \% \text { of } \\
\text { share capital of the company or } \\
20 \% \text { of Investment Fund of CIT, } \\
\text { whichever is lower. } \\
\text { Invest in a consortium with banks } \\
\text { up to } 20 \% \text { of total fixed assets } \\
\text { (up to } 50 \% \text { if company owned by } \\
\text { the GoN) or } 20 \% \text { of Investment } \\
\text { Fund of CIT, whichever is lower. }\end{array}$ \\
\hline $\begin{array}{l}\text { Hydroelectricity } \\
\text { Investment and } \\
\text { Development } \\
\text { Company Limited }\end{array}$ & $\begin{array}{c}\text { Equity \& } \\
\text { debt }\end{array}$ & 99 & 50 & 50 & $\begin{array}{l}\text { HIDCL can invest in a consortium } \\
\text { with banks up to } 25 \% \text { of its } \\
\text { capital fund. } \\
\text { Company can invest up to } 20 \% \\
\text { in the hydropower company's } \\
\text { shares or } 25 \% \text { of its capital fund, } \\
\text { whichever is lower. } \\
\text { Company can invest up to } 25 \% \\
\text { of its capital fund in hydropower } \\
\text { project as loans, bonds, or } \\
\text { debentures. }\end{array}$ \\
\hline
\end{tabular}

Sources: NRB Annual Report 2018b, Economic Survey 2018, EPF Annual Report 2018, CIT Annual Report 2018, World Bank estimates.

Note: $\mathrm{CIT}=$ Citizen Investment Trust; EPF = Employees Provident Fund; GoN = Government of Nepal; HIDCL = Hydroelectric Investment Development Company Limited; PPA = power purchase agreement.

under its "People's Investment in Nepal's Water Resources" program (MOEWRI 2018). From 2010 to 2017, 11 hydropower companies went public and raised approximately US\$19 million through their IPOs from the public and another US $\$ 10$ million from local communities. The IPOs of another 10 hydropower companies, including three NEA subsidiaries, have been completed or were underway in 2018 and could raise another US\$50 million from the share market. The 
market capitalization ratio of the hydropower sector (US\$624 million) to the total market capitalization (US\$13.2 billion) in Nepal is around 4.7 percent; 19 of the 242 listed companies in the Nepal Stock Exchange are hydropower companies.

Nepal's bond market is underdeveloped and not able to support the development of the sector. To meet short-term financing needs, the government issues short-term treasury bills and national savings certificates. The government also issues longer tenor instruments, development bonds, which are admitted for trading through the Nepal Stock Exchange. However, development bonds are rarely traded, and the size of the bond is too small to satisfy institutional investor demand. Moreover, under the prevailing market conditions, fixed deposits with banks provide the highest rate of return compared with government securities and are thus an obvious choice for investment managers. The government has on several occasions taken the initiative to mobilize funds by issuing remittance and foreign employment bonds targeted at overseas Nepalese, but, because of poor design and marketing, these have been undersubscribed.

Nepal is embarking on a significant infrastructure expansion program in the electricity sector that will require two to four times the level of investment achieved in the recent past. This expansion program seeks to correct the chronic underinvestment in the sector over many decades, which left the country with a severe electricity crisis and substantial suppressed demand. The GoN envisions roles for the public and private sectors in the infrastructure expansion, based on their respective comparative advantages. The NEA has signed local currency PPAs for more than 2,000 MW of new capacity under these guidelines with the domestic private sector. Most of these projects are looking to reach financial closure or are in the early stages of construction. The NEA anticipates developing more than 4,000 MW of hydropower projects between 2020 and 2030 through subsidiary companies.

This will require a paradigm shift in the way Nepal approaches energy sector financing. Recently, Nepal has inefficiently used the public and private sources of financing available to the sector. Prolonged political instability and poor governance have undermined public investments and disincentivized private investment. On average, power sector projects have taken more than nine years to implement. The efficiency of power sector investments has been low, with an incremental capital-output ratio of 29 for the power sector as opposed to 5.2 economywide (World Bank 2017a). The financial viability of the sector has been weak in the past, undermining the bankability of power projects. The institutional and regulatory framework has been inadequate. These factors have increased the risk perception of the electricity sector and limited the amount of commercial and private sector financing available to the sector. However, the return to political stability, the government's ambitious plan to increase generation capacity, and recent improvements in the dollar-denominated PPA structure are encouraging and steps in the right direction for greater private sector interest and may lead to additional foreign investment.

The specific risk characteristics of large hydropower projects mean that the public sector will need to have a strong role in developing these projects. All electricity projects face common issues. However, large hydropower faces additional risks and constraints resulting from (i) site specific nature of the projects; (ii) high construction risk and long construction periods; (iii) the capital-intensive nature and long payback periods; (iv) broader water management constraints; (v) environmental and social issues; (vi) political sensitivities; (vii) multipurpose benefits such as irrigation for agriculture; and (viii) unpredictable hydrology and geology. Many of these risks (for example, i, ii, iii, v, and viii) have been managed successfully by experienced private 
sector developers globally, but the public sector may retain a critical role in: (i) the preparation and due diligence of large hydropower projects, (ii) the development of realistic public-private risk-sharing arrangements, (iii) targeted long-term financing support, (iv) broader water management, (v) land acquisition in some cases, and (vi) management of multipurpose benefits (see box 3 on international experience with large hydropower and box 4 on private sector specifics).

\section{Nepal must increase both public and private financing to meet its needs for investment}

in electricity. Nepal's public debt levels remain relatively low at 30 percent of GDP, reflecting years of underspending in infrastructure, and indicate the potential for the government to raise additional financing for energy projects. Given the risk perception of the sector as well as legal, institutional, and regulatory barriers to mobilizing financing, the focus in the short term needs to be on addressing the significant capacity gaps in the sector, improving the efficiency of public investments, and improving the enabling environment for private investment. ${ }^{5}$ Over the medium and long terms, as these constraints are addressed, significantly higher levels of commercial and private sector financing may be expected to flow into the sector. Nepal's capital markets remain

\section{Box 3: International Experience with Large Hydro Projects}

Given their unique risk characteristics and the additional work and time involved in structuring and delivering a public-private partnership project, most large hydro projects in the world have historically been publicly financed. More than 70 percent of the hydro projects that are larger than 100 megawatts and were commissioned between 2014 and 2016 involved some form of public ownership; 90 percent of the largest were exclusively public projects. The private sector proportion increases as the project's scale diminishes.

TABLE B.3.1: Ownership Shares of Hydro Projects

\begin{tabular}{l|c|c}
\multicolumn{1}{c|}{ Ownership } & Projects commissioned, 2014-16 & Share (\%) \\
Wholly public & 42 & 58 \\
\hline Wholly private & 21 & 29 \\
\hline Public-private & 1 & 1 \\
\hline Foreign state-owned enterprise involvement & 8 & 11 \\
\hline
\end{tabular}

Source: International Hydropower Association 2017.

Benefits of project phasing. Given high capital expenditure costs and long construction times, interest during construction can significantly increase the cost of the project when financing is committed before it is required. Sequential financing can help remedy this, where the funding is raised when required. Of the 10 largest hydropower projects in the world, 8 have been constructed in more than one phase, thereby raising financing in sequences and using early generation as a source of income. For instance, in the case of the Grand Renaissance Dam, the government of Ethiopia is progressively raising bonds to finance different phases of the project. Similarly, the government of Pakistan is using sequential financing to develop the Dasu hydropower project. A phased approach can be adopted by public and private sector projects to save on interest during construction.

\footnotetext{
${ }^{5}$ Given relatively low public debt levels and underuse of the available concessional donor finance in the recent past, Nepal needs to focus on improving the efficiency of its public investments in the sector.
} 


\section{Box 4: Private Sector Experience with Large Hydro Projects}

With power market liberalization and increased private sector participation in emerging markets over the past few decades, governments have welcomed private developers to develop, finance, construct, and operate hydropower projects, including large hydropower projects around the world. There are several such examples, including many financed by International Finance Corporation, such as the 500-megawatt (MW) Pangue Hydroelectric project in Chile, the 500-MW Boyabat project in Turkey, and the 690-MW Barra Grande project in Brazil. Since 2000, 54 gigawatts of large hydropower projects have been developed by the private sector, with investment volume totaling more than US $\$ 73$ billion, or less than US\$1.4/watt. ${ }^{\text {a }}$ Among the larger examples is the 3,000-MW Engie-sponsored Jirau project in Brazil.

Given the geological, hydrological, seismic, environmental, social, and other complexities and associated uncertainties related to the construction of hydropower projects, cost overruns and construction delays are common features of greenfield projects. Governments and public sector utilities have been able to allocate a significant portion of such risks to the private sector in hydro independent power producers, alleviating the risk to the public sector and end consumers. For private developers and lenders, managing such risks has required thorough project assessment, careful selection of parties with strong experience in hydro development, and significant engagement in project implementation and supervision. Furthermore, robust contingency and sponsor support arrangements have helped to mitigate financing risk. With the right approach and the right sponsors, private developers and lenders have helped drive success in the development and execution of private sector-led hydropower projects. Although the risks are more pronounced in hydro development, project sponsors have a strong financial incentive to deliver projects on time and on budget, which also helps to align interests.

The most successful projects are often those that are cost competitive in the country's power generation mix and have low cost overrun risks or highly committed sponsors, falling into one of the following categories: (1) greenfield hydros with limited underground works (for example, the 250-MW Bujagali project in Uganda); (2) privatization and/or rehabilitation or expansion of existing hydros, where rehabilitation or expansion requires limited underground works (for example, the 404-MW Vorotan hydro project in Armenia); and (3) more complex greenfield projects with highly committed sponsors who have the technical sophistication, balance sheets, and dedication to address problems as they arise (for example, the 300-MW La Higuera and La Confluencia projects in Chile, where Norway's Statkraft played such a role in a commercially driven structure, voluntarily injecting additional equity and expertise when it was needed most).

a. World Bank (2018a) Private Participation in Infrastructure (PPI) Project Database. The figures correspond to greenfield projects of at least $250 \mathrm{MW}$.

TABLE B.4.1: Breakdown of Investment in PPI Database for All Countries

\begin{tabular}{l|c|c|c|c}
\multicolumn{1}{c|}{ Ownership } & Investment (US\$ million) & Capacity (MW) & Share of investment & Share of capacity \\
\hline Foreign SOI & $16,591.7$ & 9,844 & $23 \%$ & $18 \%$ \\
\hline Public-private & $40,488.18$ & 31,330 & $55 \%$ & $58 \%$ \\
\hline Private & $16,417.09$ & $13,155.4$ & $22 \%$ & $24 \%$ \\
\hline Grand total & $\mathbf{7 3 , 4 9 6 . 9 7}$ & $54,329.4$ & $100 \%$ & $100 \%$ \\
\hline
\end{tabular}

TABLE B.4.2: Breakdown of Investment in PPI Database for IDA Countries

\begin{tabular}{l|c|c|c|c} 
Ownership & Investment (US\$ million) & Capacity (MW) & Share of investment & Share of capacity \\
\hline Foreign SOI & 13,987 & 8,614 & $87 \%$ & $91 \%$ \\
\hline Public-private & 2,160 & 900 & $13 \%$ & $9 \%$ \\
\hline Grand total & 16,147 & 9,514 & $100 \%$ & $100 \%$ \\
\hline
\end{tabular}

Note: MW = megawatts; SOE = state-owned enterprise. 
at the early stage of development. With reforms, mobilizing larger amounts of financing from the capital market will be possible. Similarly, Nepal will be able to increase foreign investment in the sector.

It will be important to complement the push for increased financing with a clear and wellfounded framework for valuing contingent liabilities. The government currently lacks a framework for recording and monitoring contingent liabilities as part of the Ministry of Finance's (MOF's) fiscal oversight. This would help to (i) inform decisions of what kinds of support are worth providing during financing decisions, (ii) increase the transparency of such decisions, and (iii) alleviate concerns about fiscal prudence. 


\section{Binding Constraints to Scale Up of Financing}

To achieve its sector goals, Nepal needs to realize a twofold to fourfold increase in investments. It will be critical for Nepal to address the constraints that are currently limiting the scale-up of financing in the electricity sector. Constraints in four main areas affect the mobilization of additional finance in the sector: (i) capacity and the enabling environment, (ii) financial viability, (iii) availability of long-term financing, and (iv) foreign investments.

\subsection{Constraints Affecting Capacity and the Enabling Environment}

Nepal is embarking on a significant infrastructure expansion program at a time when local capacity to undertake these investments is limited and the efficiency of sector investments is low. Two decades of conflict and political instability, together with depletion of pay and benefits, have sapped the morale and culture of government agencies. The massive outmigration of skilled and unskilled labor has resulted in a scarcity of medium- to high-skilled technical and managerial workers in Nepal, posing a challenge for the sector expansion program. Nepalese firms will increasingly need to compete at the regional and international levels for expertise and talent. Strict visa regulations for foreign workers, the lack of a distinction between temporary and permanent movements of workers, and the nontransparent and expensive visa process exacerbate the situation. Lack of international developers in the recent past has also reduced the knowledge transfer that took place with the early IPPs.

There is a need to build the capacity of new public sector agencies in the electricity sector and assist them in leveraging additional financing, including private and commercial financing. The government has established new institutions in the electricity sector-NEA subsidiary companies, Electricity Generation Company Limited (EGCL), National Grid Transmission Company Limited (NGTCL), Nepal Power Trading Company Limited (NPTCL), and Nepal Engineering Services Limited-to support the infrastructure expansion program (see box 5 on building effective institutions). NEA subsidiary companies have mobilized substantial resources to develop priority hydropower projects, but they need capacity building to manage risks and complete complex hydropower projects on time and within budget. EGCL needs to be developed as a specialized agency with in-depth technical and project development expertise in storage hydro projects, which the NEA and IPPs currently lack. NEA subsidiary companies and EGCL need to be enabled to leverage additional financing from different sources, including private and commercial, for the development of the sector.

The public investment management and planning process is highly inefficient and has recently failed to deliver completed productive assets and infrastructure on time. Power sector projects on average have taken more than nine years to finish, significantly longer than 


\section{Box 5: Building Effective Institutions}

The performance of institutions depends not just on formal organizational rules and structures but also the informal norms and incentives of people responsible for implementing these rules. Once poor systems are in place, they can be very difficult to dislodge. Strong interests develop in maintaining the status quo, however inefficient or unfair.

Therefore, institutional building efforts must focus on shaping incentives in addition to providing knowledge, training, and modern equipment. Effective institutions need to be incentive compatible. Institutions with internal enforcement mechanisms are effective because there is a mutually recognized system of rewards and penalties. An important issue in the design of public institutions is ensuring that the incentives that are created lead to desired behavior.

Source: World Development Report 2017.

international benchmarks. Investments are selected on a project-by-project basis without adequate consideration of the technical and economic merits of the projects or coordination with other investment decisions. The use of formal river basin plans and least-cost plans to inform the priority order of investments is absent. The public investment management process in Nepal is relatively weak compared with similar countries. Nepal has failed to enforce public investment management features, such as project selection and budgeting, project implementation, adjustment of projects in construction, and ex post evaluation.

The private sector is eager for a greater role in the development of the sector but lacks a level playing field against the NEA. NEA functions include power generation and system dispatch, in addition to owning and operating the national T\&D system. Private IPPs are expected to bring large-scale investments into hydropower generation, but they are at a disadvantaged position in transmission access, dispatch, and PPA negotiations with the NEA, which prioritizes its own power plants. Private developers do not have unfettered access through the transmission system to large buyers in the domestic and regional markets and are thus not able to develop projects without a PPA with the NEA.

The absence of a strong, transparent, and professional regulatory agency has increased the risk perception of the sector among investors. A strong regulatory system is designed to ensure fair treatment of customers and investors. It gives confidence to investors that their investments will be safeguarded to earn a fair return. Despite consensus on the need for an independent regulator, Nepal had not been able to establish one for the past decade. Nepal's parliament passed the enabling legislation for an independent regulatory agency in September 2017. The regulator needs to be operationalized to ensure the development of a receptive investment climate. In Nepal's context, it is urgent that the regulator develop guidelines on electricity tariffs, transmission pricing, grid code, and open-access/third-party access, to send the right signals to investors and facilitate competition in the sector.

\subsection{Constraints Affecting Financial Viability}

The financial viability of the sector needs to be strengthened to enable it to mobilize the resources it needs from debt and capital markets. The financial situation of Nepal's electricity sector has been very weak in the past. In the years leading to FY2017, the NEA posted large losses caused by below-cost retail electricity tariffs and high system losses. The NEA's cumulative losses 
between 2008 and 2016 (US\$643 million) equaled 3 percent of GDP (figure 3). ${ }^{6}$ T\&D losses in Nepal, at 25.8 percent in FY2016, were significantly higher than regional and international benchmarks (NEA 2018b). This severely limited the NEA's ability to make new investments and sign PPAs with IPPs, which contributed to the country's electricity sector crisis. After 10 years of operating at a loss, the NEA began operating at a profit in FY2017, largely because of a 14 percent increase in tariffs and implementation of a financial restructuring plan (see Appendix 2). Yet, a sustained focus on increasing revenue, reducing system losses, and financing costs will be needed in the coming years to enable the NEA to meet its PPA obligations and maintain robust financial health.

FIGURE 3: NEA Net Income (US\$ million)

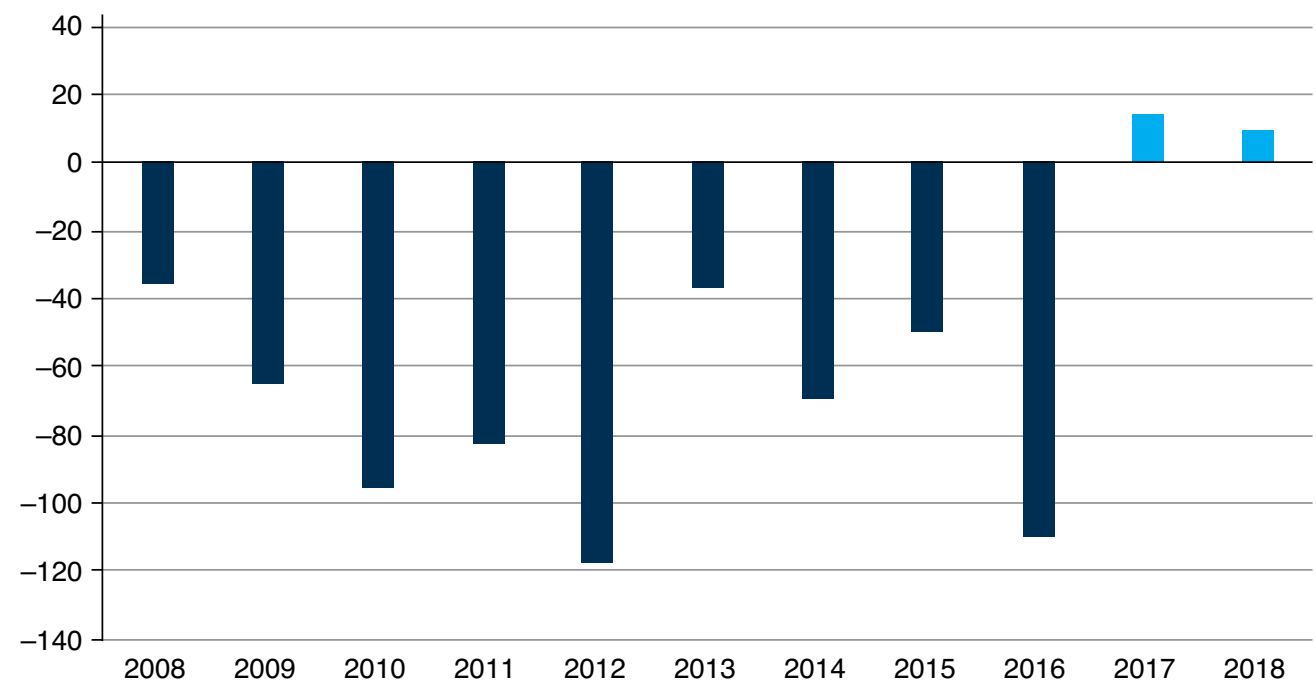

Source: NEA Annual Report 2018b.

This will mean developing a framework and capacity for electricity trade with Nepal's neighbors. The generation from Nepal's hydropower plants falls by two-thirds during the dry winter season (figure 4). Without a strong institutional and regulatory framework to manage the country's electricity trade, Nepal will not be able to find markets for its surplus generation in the wet months and cheap imports in the dry season. As a result, the average cost of electricity served to Nepal's consumers will increase, which could adversely affect the sector's financial viability. Nepal currently lacks a dedicated institution to manage the country's electricity trade, and a legal and regulatory framework for electricity trade at the national and regional levels.

With financial viability, the NEA would improve its ability to mobilize financing from debt and capital markets on its own without government support. With improvements in its operational and financial performance, the NEA would increasingly be able to raise its own capital directly from commercial banks or by issuing corporate bonds, reducing the need for direct budgetary support from the government. The NEA would need to demonstrate sound financials

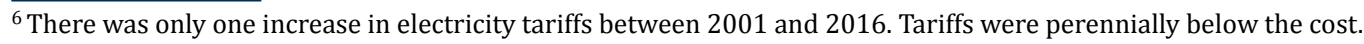


FIGURE 4: Streamflow $\left(\mathrm{M}^{3} / \mathrm{S}\right)$ in the Location for Upper Arun Hydropower Project

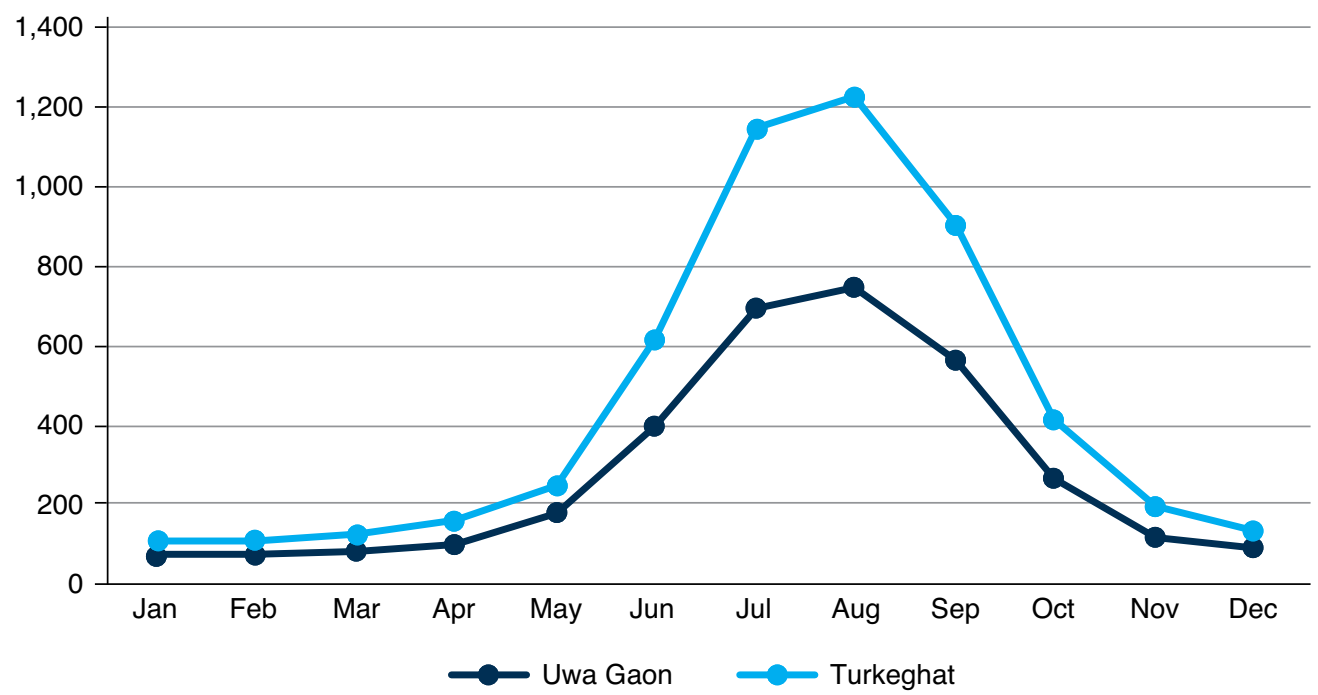

Note: $\mathrm{M}^{3} / \mathrm{S}$ = cubic millimeters per second.

through a combination of efficient performance, a stable but flexible tariff regime, and reliable budget support, as quantified by an adequate credit rating from a reputable risk-rating agency.

\subsection{Constraints Affecting the Availability of Long-Term Financing}

The ability of banks, which dominate the financial sector, to intermediate and provide long-term finance to the electricity sector is constrained by several factors. Nepal's banks face a significant asset-liability mismatch in lending to long-term hydropower projects because of the banks' mostly short-term deposits. There is a lack of nonrecourse project finance in the sector, because Nepal Rastra Bank (NRB) regulations discourage non-collateral-based lending. Bank lending is further constrained by the limited capacity of banks to conduct detailed due diligence; the high-risk perception of the hydropower sector, given past cost and time overruns; high collateral requirements; and the prevailing weak standards of corporate governance, especially relating to timely corporate actions and release of information. With loan growth far exceeding deposit mobilization, electricity sector projects face high interest rates. The single-borrower limit of 50 percent of the banks' equity capital constrains lending and necessitates lending from a consortium of banks for projects requiring more than US $\$ 40$ million.

Sector-specific financiers cannot fill the gap left by commercial banks. In 2011, HIDCL was set up as a special-purpose vehicle to make debt and equity investments in medium-size and large hydropower projects. It has authorized capital of US\$435 million and paid-in capital of US\$87 million. The company is majority owned by the GoN (50 percent), with institutional investors (30 percent) and public investors (20 percent) making the remaining equity contributions. So far, HIDCL has provided debt and equity financing of about US\$50 million to 11 hydropower projects. The sizes of the commitments range from US $\$ 1.7$ million (Bagmati Small Hydropower project, $20 \mathrm{MW}$ ) to US\$5.2 million (Lower Sulu, $82 \mathrm{MW}$ ). Furthermore, HIDCL has invested in the 
Nepalese portion of the cross-border Dhalkebar-Muzaffarpur transmission line. It has incorporated a fully owned subsidiary, Remit Hydro Limited, to raise funds from the Nepalese diaspora for investment in hydro generation and transmission. Similar to domestic banks and financial institutions, HIDCL's institutional and financial capacities need to be strengthened substantially to support the infrastructure expansion program in the sector.

Nepal's capital markets are at an early stage of development and need deepening to play a significant role in the provision of long-term finance to the electricity sector. Long-term, committed funding for infrastructure projects is best supported by a mature and vibrant bond market. Nepal's bond market remains constrained, accounting for about 13 percent of GDP at the end of 2017. The debt market is dominated by short-term government debt, and there is no active yield curve. There are few investors in debt instruments, and treasury instruments are bought largely by banks to satisfy statutory liquidity requirements. The lack of a reliable issuance calendar, minimal volumes in the primary market, and negligible liquidity in the secondary market all contribute to the lack of a liquid sovereign benchmark. Nepal's policies and regulations governing the financial markets, banking sector, and government securities tend to discourage the development of the bond market. Secondary trading is negligible, because of the lack of an investor base and inadequate clearing and settlement systems. Attention needs to be given to improving laws, regulations, and supervision for bond market development (Asian Development Bank 2014).

The equity market is shallow, limiting the government's ambitions to use it to mobilize investments in hydropower. The stock market needs modernization. The Securities Board of Nepal lacks autonomy and capacity to provide effective risk-based supervision. Private equity and venture capital lack a specific legal and regulatory framework. The government has launched a program to broaden the ownership base of hydropower in the country through requirements for public projects to issue 10 percent of the shares to local communities and at least 15 percent of the shares to the public through IPOs. This investment model offers great potential to create local ownership and increase public support for hydropower projects. However, it will be important to address the widespread lack of understanding of how the market mechanism works and institute effective safeguards to reduce risk to investors and local communities (ICIMOD and Niti Foundation 2016).

Local institutional investors are underdeveloped and mostly invest in short-term instruments. The assets of insurance companies, pension funds, and mutual funds can be critical in safely funding long-term investment. There are potential domestic institutional investors, including the Employees Provident Fund, Citizen Investment Trust, and the insurance sector, with a combined asset size of around 15 percent of GDP. An important factor inhibiting the development of institutional investors is the capacity of the regulator, with priority needed for risk-based supervision along with risk-based capital, as well as stronger asset-liability management. Insurance companies need capacity building to underwrite loans to large projects and PPPs, product diversification, and price diversity (USAID 2018).

\subsection{Constraints Affecting Foreign Investments}

Foreign exchange risks significantly constrain the attraction of foreign investment to the sector. In recent years, the government has shown greater appreciation of the importance of foreign investment for meeting sectoral investment targets and receiving skills and knowledge 
transfer in the hydropower sector. The government adopted PPA guidelines in 2017 that offer partial foreign currency-denominated PPAs for projects larger than $100 \mathrm{MW}$ with foreign financing, with a provision to cover the foreign debt incurred by developers through U.S. dollardenominated payments for 10 years. The government is also keen to establish a hedging mechanism for better management of foreign exchange risks in the sector. Although both mechanisms are progressing in the right direction, as currently structured, they are not expected to be adequate to attract foreign investment (box 3).

FDI inflows have been hurt by unclear policies, complex procedures, and inadequate investment facilitation. Offshore funds and onshore vehicles with foreign shareholders are considered foreign investors; therefore, they require FDI approval for every new investment in a Nepalese company. FDI approvals can take several months and include lengthy processes to hire foreign workers. Many of these problems derive from practice more than from the law itself. For example, although firms are formally allowed to open U.S. dollar-denominated accounts, small firms and individuals report that this is difficult in practice. Even with such an account, it is difficult to pay for services in U.S. dollars, because of caps on the size of U.S. dollar-denominated contracts. In addition, many FDI guidelines are only available in Nepalese and have not been translated into English.

There is limited access to foreign currency lending. The provisions of the Banks and Financial Institutions Act make foreign currency investment and lending difficult. The central bank, the NRB, has set strict limits on lending by foreign institutions, which is allowed only in the case of unavailability of domestic debt and is subject to an interest rate cap of LIBOR +5.5 percent. Moreover, foreign lenders do not enjoy the same level of protection as local banks in terms of creditors' rights. Although land and buildings are the main forms of collateral for lending, mortgaging of

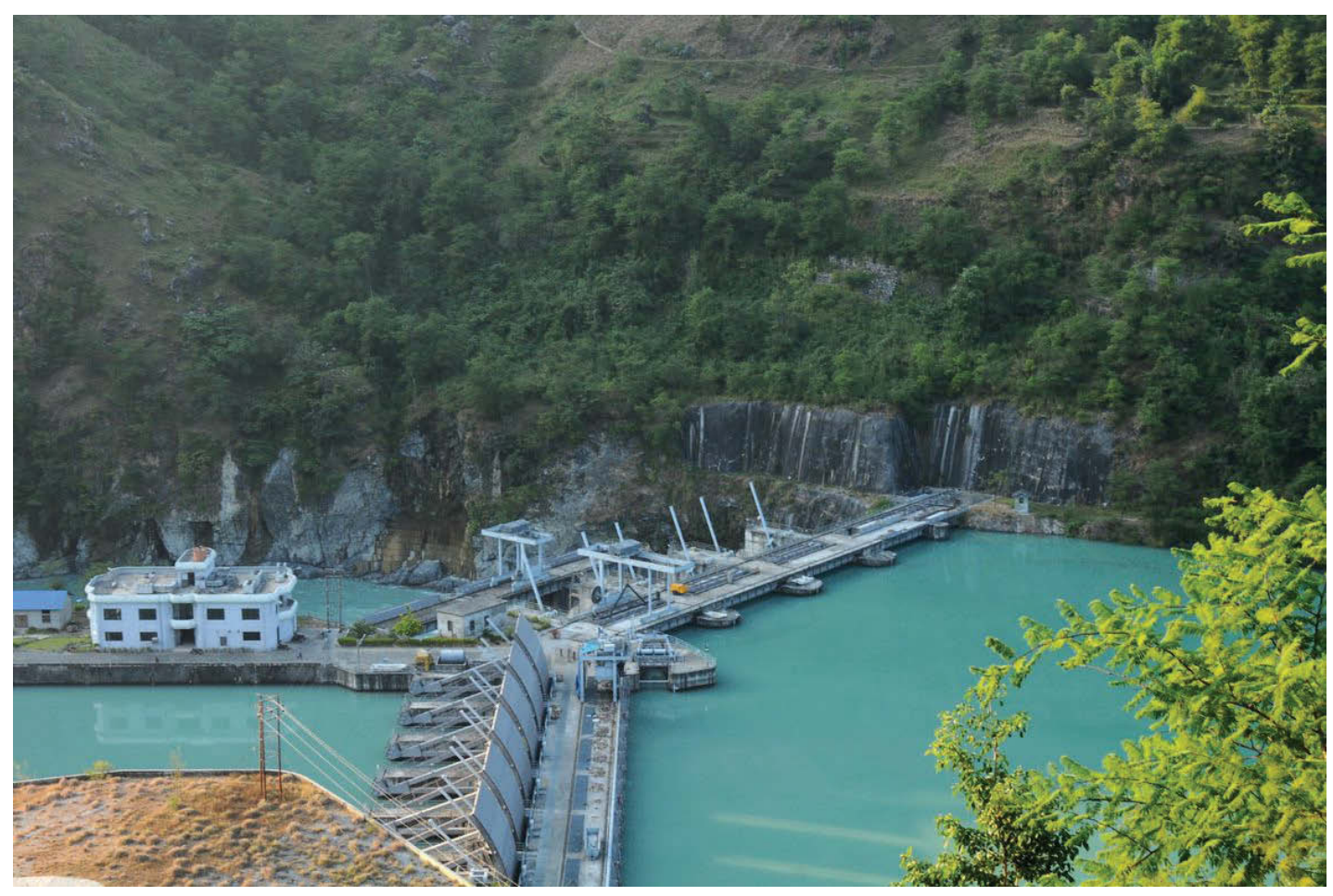


property in favor of foreign lenders needs cabinet approval, and enforcement of security requires a court order. Furthermore, foreign lenders are subordinated to local banks in priority of repayment, and borrowing is capped in terms of amount and pricing.

Nepal has a complicated process for offshore capital repatriation. Nepal has a fixed currency regime (pegged to the Indian rupee). Offshore funds require approval of the NRB to repatriate the proceeds of their divestments. Approvals are granted only for amounts calculated under valuation rules set by the regulator, not for the actual proceeds. Strict foreign exchange controls create an incentive for undervaluing transactions so that less foreign exchange leaves the country. Furthermore, despite the country's many double taxation agreements, there has been uncertainty about their enforcement, which increases uncertainty for foreign investors when exiting investments. 


\section{Roadmap to Unlock New Sources of Finance}

A coordinated policy effort in four areas is required to meet the financing needs of the electricity sector. Nepal's investment needs are two to four times higher than its recent investments in the sector. Nepal needs to use available financing, but this will not be sufficient to meet the large financing needs of the sector. To do so, the country must develop and tap into newer and larger sources of local and international financing. To seize this opportunity, the government is advised to exert a sustained and concerted policy effort in four main areas:

Pillar 1: Build the institutional and regulatory environment

Pillar 2: Strengthen the financial viability of the sector

Pillar 3: Increase the availability of long-term finance

Pillar 4: Develop an enabling environment for foreign investment.

\subsection{Build the Institutional and Regulatory Environment}

Any effort to increase financing in Nepal's electricity sector must start by improving the use and efficiency of available financing. This will help lower the risk perception of the electricity sector in Nepal and enable additional sources of financing to flow into the sector. By addressing the knowledge and capacity gaps in the sector and providing a level playing field to the private sector, the government will enable the private sector to increase its role in the electricity sector (see table 4).

\section{Address Knowledge and Capacity Gaps}

- In the private sector. Nepal's private sector currently lacks the contractor capacity, technical and managerial expertise, project appraisal and risk management expertise, and trained workers that are necessary to undertake successfully a large infrastructure program in the electricity sector. There is a need to assess and address the workforce, contractor capacity, education, and training constraints in the sector. For FDI projects, partnerships between local developers and experienced international developers can enable development of this local capacity in the areas of project management, technology transfer, contract management, and construction methods.

- In the public sector. The GoN established EGCL and NGTCL to support electricity sector expansion. These institutions need to be developed into modern, capable, and efficient institutions that can attract and retain talent. At the same time, the NEA should be corporatized and modernized in preparation for its planned restructuring. It is recommended that the government ensure that the functioning of these institutions is not adversely affected by political interference, and that these institutions have the capacity 
TABLE 4: Build the Institutional and Regulatory Environment-Recommended Actions

\begin{tabular}{|c|c|c|}
\hline $\begin{array}{l}\text { Key constraints } \\
\text { (responsibility) }\end{array}$ & Short-term actions & Medium-term actions \\
\hline \multicolumn{3}{|c|}{ Limited capacity and know-how in the sector } \\
\hline $\begin{array}{l}\text { Private sector } \\
\text { (MOEWRI) }\end{array}$ & $\begin{array}{l}\text { Prepare diagnostic and strategy to address } \\
\text { capacity constraints in the private sector. }\end{array}$ & Implement the strategy. \\
\hline $\begin{array}{l}\text { Public sector } \\
\text { (MOEWRI) }\end{array}$ & $\begin{array}{l}\text { Prepare business plans for new electricity } \\
\text { sector institutions, such as EGCL and RGPCL. } \\
\text { Carry out an organizational stocktaking and } \\
\text { diagnostic of NEA. } \\
\text { Corporatize distribution companies } \\
\text { and explore options for private sector } \\
\text { participation. } \\
\text { Develop a robust and transparent bidding } \\
\text { framework for procuring energy projects by } \\
\text { PPP, including developing internationally } \\
\text { bankable PPAs and PDAs. } \\
\text { Adopt competitive bidding guidelines for } \\
\text { hydropower and solar. }\end{array}$ & $\begin{array}{l}\text { Implement the business plans. } \\
\text { Implement the recommendations of the } \\
\text { NEA diagnostic. }\end{array}$ \\
\hline $\begin{array}{l}\text { Public investment } \\
\text { management } \\
\text { (MOF/MOEWRI) }\end{array}$ & $\begin{array}{l}\text { Establish a central coordination and } \\
\text { investment management mechanism for } \\
\text { energy projects. }\end{array}$ & $\begin{array}{l}\text { Implement mechanism to ensure close } \\
\text { coordination between federal and } \\
\text { provincial entities in implementation of } \\
\text { energy projects. }\end{array}$ \\
\hline $\begin{array}{l}\text { Planning } \\
\text { (NEA/ERC) }\end{array}$ & $\begin{array}{l}\text { Prepare the river basin plan. } \\
\text { Prepare a least-cost generation master plan. } \\
\text { Prepare distribution master plan. }\end{array}$ & $\begin{array}{l}\text { Monitor and update the plans. } \\
\text { Use competitive bidding for next wave } \\
\text { of hydro and solar IPPs. } \\
\text { Use a build-and-transfer model to } \\
\text { develop transmission projects with } \\
\text { private sector participation. }\end{array}$ \\
\hline $\begin{array}{l}\text { Environment } \\
\text { and social } \\
\text { (MOFEP/NEA/MOF) }\end{array}$ & $\begin{array}{l}\text { Adopt improved land acquisition, forest } \\
\text { clearance, right-of-way, and gender and social } \\
\text { inclusion guidelines. }\end{array}$ & $\begin{array}{l}\text { Strengthen the capacity of relevant } \\
\text { agencies to implement these } \\
\text { guidelines. }\end{array}$ \\
\hline \multicolumn{3}{|c|}{ Absence of level playing field for the private sector } \\
\hline $\begin{array}{l}\text { Independent regulator } \\
\text { (MOEWRI/ERC) }\end{array}$ & $\begin{array}{l}\text { Appoint ERC chairman and commissioners. } \\
\text { Prepare an ERC business plan. }\end{array}$ & $\begin{array}{l}\text { Implement an ERC business plan that } \\
\text { covers the points above on fixing a new } \\
\text { tariff-setting mechanism for IPPs and } \\
\text { establishing power-wheeling charges } \\
\text { for the use of NEA transmission } \\
\text { facilities. }\end{array}$ \\
\hline $\begin{array}{l}\text { Sector restructuring } \\
\text { (MOEWRI) }\end{array}$ & $\begin{array}{l}\text { Prepare and approve the new Electricity Act. } \\
\text { Issue a sector restructuring plan. }\end{array}$ & $\begin{array}{l}\text { Complete the separation of the } \\
\text { NEA's generation, transmission, and } \\
\text { distribution business under a holding } \\
\text { company structure. }\end{array}$ \\
\hline
\end{tabular}

Note: $\mathrm{EGCL}=$ Electricity Generation Company Limited; ERC = Electricity Regulatory Commission; IPP = independent power producer; MOEWRI = Ministry of Energy, Water Resources, and Irrigation; MOF = Ministry of Finance; MOFEP = Ministry of Finance and Economic Planning; NEA = Nepal Electricity Authority; PDAs = project development agreements; PPAs = power purchase agreements; PPP = public-private partnership; RPGCL = Rastriya Prasaran Grid Company Limited. 
and resources to deliver their mandate. Public sector companies could outsource selected operation and management functions to experienced private sector companies.

- In public investment management. It is advised that the government establish a wellresourced, central coordination mechanism for the energy sector, preferably in the Prime Minister's Office. The unit would support the following activities: (i) strategic planning, (ii) prioritization and selection of projects and maintenance of a rolling pipeline of priority infrastructure projects, (iii) coordination of government agencies and the Investment Board Nepal (IBN), (iv) transparent performance monitoring, and (v) preparation and implementation of initiatives in favor of private sector investment in priority infrastructure. The new mechanism would apply a clear decision-making framework to prioritize private financing and leverage scarce public resources.

- In power system planning. There is a need for substantial strengthening of the planning function in the energy sector and using it to inform decisions. It would be advisable for the government to complete and regularly update the river basin plan and the generation, transmission, and distribution master plans. Moreover, there is need for a concerted effort to incorporate a culture of planning in electricity sector institutions. The NEA should introduce competitive bidding in the next wave of IPPs in hydropower and solar and bid out selected high-voltage transmission lines to the private sector using the PPP models.

- In environment and social inclusion. As Nepal prepares to develop large ROR and strategically important storage hydropower projects, it will need clear and consensus-based guidelines for resettlement and rehabilitation, land acquisition, and other mitigation support for people affected by the projects. It will also need strengthened and streamlined environmental and social provisions for investment. It would be advisable for the government to adopt new forest clearance, right-of-way, and gender and social inclusion guidelines and strengthen its capacity to implement these guidelines.

\section{Create a Level Playing Field for the Private Sector}

- By operationalizing an independent regulator. Until FY2019, Nepal has not had an independent electricity regulator. Nepal's parliament approved the Electricity Regulatory Commission Act in September 2017. The regulator is expected to set prices, ensure efficient provision of services, monitor the abuse of market power, and ensure open and fair access to the transmission system. The government is advised to develop a strong regulator, by making key appointments in the near term and supporting its institutional development in the medium term. An efficient and effective regulatory framework will help provide confidence to private investors regarding fair treatment in a rule-based sector and help increase investments. There is a need for greater transparency and stronger regulations on the use of the NEA's transmission infrastructure by IPPs to export power. Currently, there is no transparency on how IPPs can access this physical infrastructure, and there is no regulation, for example, on wheeling charges.

- By completing the electricity sector restructuring process. It is recommended that Nepal pursue structural reforms in the sector to increase investments. Given the prospect of surplus generation in the wet season and the inability of the NEA to offer take-or-pay contracts to all developers, investors' access to large domestic customers and the Indian and regional electricity markets would ensure the viability of their investments. A new Electricity Act to redefine the roles and responsibilities of different sector institutions and 
a sector restructuring plan are crucial for ensuring private developers' unfettered access to the domestic and regional electricity markets. For instance, a single buyer could negotiate PPAs with IPPs rather than the NEA, which has its own generation assets and PPAs with semiprivate subsidiaries and potential conflicts of interest. Alternatively, the government could consolidate all the public generation companies into a single entity, which would not be the off taker for IPPs.

- By establishing a one-stop window for private sector IPPs. It is recommended that the government set up a one-stop window for private sector IPPs, or enhance the role of the IBN to act effectively as a single processing entity.

\subsection{Strengthen the Financial Viability of the Sector}

Improved financial viability would increase the ability of electricity sector institutions to mobilize financing from the capital market (table 5). A financially viable sector means full recovery of the cost of electricity services, reasonable revenue for reinvestment, system losses on par with international benchmarks, and a subsidy mechanism in place to ensure affordable electricity services for the poor. This can be achieved by taking policy actions to improve the creditworthiness of electricity sector institutions and by strengthening the enabling conditions for electricity trade with Nepal's neighbors.

\section{Improve the Creditworthiness of the Sector}

- By ensuring cost-reflective tariffs. The regulator will establish a cost-reflective tariff framework to improve the NEA's financial health and provide predictability for sustainable investment in the power sector. This will improve the NEA's ability to make new investments and sign PPAs with IPPs.

TABLE 5: Improve the Financial Viability of the Sector-Recommended Actions

\begin{tabular}{|c|c|c|}
\hline $\begin{array}{l}\text { Key constraints } \\
\text { (responsibility) }\end{array}$ & Short-term actions & Medium-term actions \\
\hline \multicolumn{3}{|c|}{ Poor creditworthiness of electricity sector institutions } \\
\hline $\begin{array}{l}\text { Cost-reflective tariffs } \\
\text { (ERC) }\end{array}$ & $\begin{array}{l}\text { Issue new electricity tariff } \\
\text { guidelines. }\end{array}$ & $\begin{array}{l}\text { Approve tariff revisions annually } \\
\text { based on tariff guidelines. }\end{array}$ \\
\hline $\begin{array}{l}\text { Loss reduction } \\
\text { (NEA) }\end{array}$ & $\begin{array}{l}\text { Approve the Loss Reduction Master } \\
\text { Plan. }\end{array}$ & Implement the master plan. \\
\hline $\begin{array}{l}\text { Financial viability plan } \\
\text { (NEA) }\end{array}$ & $\begin{array}{l}\text { Prepare the NEA to access capital } \\
\text { and debt markets on its own } \\
\text { by implementing the } 2018 \text { NEA } \\
\text { Financial Viability Action Plan. }\end{array}$ & $\begin{array}{l}\text { Explore options to obtain a credit } \\
\text { rating for the NEA and its subsidiary } \\
\text { companies. }\end{array}$ \\
\hline \multicolumn{3}{|c|}{ Weak enabling framework for electricity trade } \\
\hline $\begin{array}{l}\text { Regulations and guidelines } \\
\text { (MOEWRI/ERC) }\end{array}$ & $\begin{array}{l}\text { Adopt electricity trading as a } \\
\text { licensed activity. } \\
\text { Issue open-access guidelines, } \\
\text { transmission guidelines, and grid } \\
\text { code. }\end{array}$ & $\begin{array}{l}\text { Harmonize with regional trading } \\
\text { guidelines and codes. }\end{array}$ \\
\hline $\begin{array}{l}\text { Institutional development of NPTCL } \\
\text { (NEA/MOEWRI) }\end{array}$ & $\begin{array}{l}\text { Adopt NPTCL business plan and } \\
\text { operating procedures. }\end{array}$ & $\begin{array}{l}\text { Commence power trading through } \\
\text { NPTCL. }\end{array}$ \\
\hline
\end{tabular}

Note: ERC = Electricity Regulatory Commission; MOEWRI = Ministry of Energy, Water Resources, and Irrigation; NEA = Nepal Electricity Authority; NPTCL = Nepal Power Trading Company Limited. 
- By reducing T\&D losses. T\&D losses in Nepal, at 20 percent in FY2018, have decreased in the past two years but are still significantly higher than global and regional benchmarks. To address this problem, the NEA should adopt and implement a Loss Reduction Master Plan. This plan would entail assessing baselines and targets for the technical and commercial losses in the distribution networks, appraising investment needs to reinforce and upgrade the electricity distribution system, and implementing comprehensive institutional and investment measures. Loss reduction will help reduce the cost of power supply and thus improve the financial viability of the electricity sector.

- By implementing the NEA's financial viability plan. The NEA adopted a Financial Viability Action Plan in 2018 to sustain the short-term improvement and ensure the long-term viability of the sector. This plan, with a 10-year outlook, calls for actions to optimize (i) cost through integrated generation and transmission planning, energy banking, reduction in T\&D losses, and appropriate management of foreign exchange risks; and (ii) revenue through restructuring the financial arrangements between the NEA and its subsidiaries, strengthening the power trading and export strategy, waiving past liabilities of the NEA, separating transmission and system operation functions, and implementing energy efficiency measures. Going forward, the NEA needs to update and implement the action plan on a consistent basis. Once it has established a sustained track record of positive financial performance, the NEA can explore options to be rated on local and international capital markets.

\section{Strength the Framework for Electricity Trading}

- Through new regulations and guidelines. Electricity trading will have an important role in improving the affordability of electricity in Nepal and ensuring the financial viability of the sector. The average cost of electricity is projected to be at least 30 percent lower with electricity trading than otherwise. Adoption of electricity trading as a licensed activity in the proposed Electricity Act would facilitate electricity trading. The new electricity regulator would need to issue guidelines on transmission pricing, open access/ third-party access to the transmission system, and the grid code. Nepal would also need to harmonize its guidelines and regulations with neighboring countries.

- Through the institutional development of NPTCL. The GoN established NPTCL in 2016 to promote domestic and regional trade of electricity. In the short term, NPTCL will focus on bridging the supply gap through imports from India. In the medium term, once substantial generation capacity that is currently under construction comes online, NPTCL will help find a market for the surplus generation from NEA generation plants and takeand-pay IPPs. NPTCL will also have a role in maximizing the revenue from the sale of free power allocated to the GoN in various export-oriented projects and attracting viable investments by entering into commercial arrangements with sellers and buyers through back-to-back PPAs. Implementation of NPTCL's business plan will facilitate the institutional development of NPTCL. Initially, the plan will be supported by NPTCL's paid-in capital. Over time, its trading fees and income will fund NPTCL.

\subsection{Increase the Availability of Long-Term Finance}

There is an urgent need to increase the availability of long-term local finance in the sector (table 6). Electricity sector projects would benefit from greater availability of long-term, fixed-interest local currency finance through the domestic debt and capital markets. Local 
TABLE 6: Increase the Availability of Long-Term Finance-Recommended Actions

\begin{tabular}{|c|c|c|}
\hline $\begin{array}{l}\text { Key constraints } \\
\text { (responsibility) }\end{array}$ & Short-term actions & Medium-term actions \\
\hline \multicolumn{3}{|c|}{ Limitations of domestic financing institutions } \\
\hline $\begin{array}{l}\text { Project appraisal } \\
\text { (NRB) }\end{array}$ & $\begin{array}{l}\text { Implement a capacity-building } \\
\text { program for domestic banks on } \\
\text { project appraisal of hydropower. }\end{array}$ & \\
\hline $\begin{array}{l}\text { Project finance } \\
\text { (NRB) }\end{array}$ & $\begin{array}{l}\text { Make legal and regulatory revisions } \\
\text { to enable nonrecourse project } \\
\text { finance and issue a Code of Practice } \\
\text { for Project Finance. }\end{array}$ & $\begin{array}{l}\text { Pilot nonrecourse finance in a } \\
\text { national priority project. }\end{array}$ \\
\hline \multicolumn{3}{|c|}{ Limited institutional and financial capacity of HIDCL and institutional investors } \\
\hline $\begin{array}{l}\text { Institutional capacity } \\
\text { (MOEWRI/HIDCL/MOF) }\end{array}$ & $\begin{array}{l}\text { Undertake twinning arrangements } \\
\text { for HIDCL with similar institutions in } \\
\text { more advanced countries, and carry } \\
\text { out capacity building and training for } \\
\text { HIDCL staff. }\end{array}$ & $\begin{array}{l}\text { Use strategic investors and/or a } \\
\text { partnership or combination with } \\
\text { a domestic commercial bank to } \\
\text { improve HIDCL's risk management } \\
\text { and project appraisal capacities. }\end{array}$ \\
\hline $\begin{array}{l}\text { Financial capacity } \\
\text { (HIDCL/Insurance Board/MOF) }\end{array}$ & $\begin{array}{l}\text { Adopt a capital increase plan for } \\
\text { HIDCL. } \\
\text { Issue revised investment guidelines } \\
\text { to increase investment opportunities } \\
\text { for insurance companies and partly } \\
\text { address asset-liability mismatches. }\end{array}$ & $\begin{array}{l}\text { Strengthen the capital base of } \\
\text { HIDCL through additional equity } \\
\text { infusions from the GoN and/or } \\
\text { development partners and/or } \\
\text { other strategic investors and/or a } \\
\text { partnership or combination with a } \\
\text { domestic commercial bank. } \\
\text { Adopt regulations related to asset- } \\
\text { liability management and solvency } \\
\text { capital requirements of insurance } \\
\text { companies. }\end{array}$ \\
\hline \multicolumn{3}{|c|}{ Limited financing from capital markets } \\
\hline $\begin{array}{l}\text { Multilateral guarantees } \\
\text { Stapled finance structures } \\
\text { (MOF/MOEWRI) }\end{array}$ & $\begin{array}{l}\text { Develop a strategy to raise financing } \\
\text { for the sector from international } \\
\text { and/or local capital markets using } \\
\text { multilateral guarantees, stapled } \\
\text { finance structures, and/or other risk } \\
\text { mitigation instruments. }\end{array}$ & $\begin{array}{l}\text { Pilot the use of multilateral } \\
\text { guarantees, stapled finance } \\
\text { structures, and/or other risk } \\
\text { mitigation instruments to raise } \\
\text { financing from capital markets in a } \\
\text { national priority project. }\end{array}$ \\
\hline $\begin{array}{l}\text { Equitization } \\
\text { (MOF/MOEWRI/NEA) }\end{array}$ & $\begin{array}{l}\text { Prepare a strategy to pursue } \\
\text { equitization of public shareholding } \\
\text { in generation entities/assets } \\
\text { (including an asset recycling } \\
\text { framework) in the electricity sector. }\end{array}$ & $\begin{array}{l}\text { Implement the strategy and } \\
\text { framework. }\end{array}$ \\
\hline $\begin{array}{l}\text { Bonds } \\
\text { (MOF/NRB) }\end{array}$ & $\begin{array}{l}\text { Prepare and adopt a bond market } \\
\text { development roadmap with a } \\
\text { medium- and long-term vision. }\end{array}$ & $\begin{array}{l}\text { Implement bond issuances (such as } \\
\text { hydro and diaspora bonds) to meet } \\
\text { financing needs in the electricity } \\
\text { sector according to the calendar laid } \\
\text { out in the roadmap. }\end{array}$ \\
\hline $\begin{array}{l}\text { Stock market } \\
\text { (MOF/Securities Board of Nepal) }\end{array}$ & $\begin{array}{l}\text { Prepare and implement a } \\
\text { communications program on } \\
\text { share investments in hydropower } \\
\text { targeted at retail investors and local } \\
\text { communities. }\end{array}$ & $\begin{array}{l}\text { Decentralize brokerage service by } \\
\text { requiring current brokers to offer } \\
\text { services at the district level and } \\
\text { allowing banks to provide this as an } \\
\text { additional service. }\end{array}$ \\
\hline
\end{tabular}

Note: GoN = government of Nepal; HIDCL = Hydroelectric Investment Development Company Limited; $\mathrm{MOEWRI}=$ Ministry of Energy, Water Resources, and Irrigation; MOF = Ministry of Finance; NEA = Nepal Electricity Authority; NRB $=$ Nepal Rastra Bank. 
currency financing is attractive because it helps avoid the additional risks associated with exchange rate variations and currency convertibility. Nepal's public debt level, at 30 percent of GDP, is low compared with regional and international benchmarks, indicating the potential to mobilize additional financing. Nevertheless, at present, it is not possible to mobilize significant amounts of local financing, because of variable interest rates, short tenors, inefficient regulations, and low capacity. Addressing these constraints will call for a concerted effort to deepen and broaden Nepal's capital markets, as an alternative channel of long-term finance. Some actions for consideration are highlighted as follows.

\section{Address Constraints Faced by Local Commercial Banks}

- In project appraisal. Many local banks are unfamiliar with hydropower projects. This makes it difficult for them to appraise projects and manage risks. For local banks to play a greater future role in electricity finance, it will be important to undertake capacitybuilding activities with the banks.

- In nonrecourse project finance. NRB regulations need to be revised to enable nonrecourse project finance where future cash flows and the assets and rights of the project are the sole collateral for lenders. Current regulations discourage lenders from taking security for loans against intangible assets. Furthermore, enabling conditions for project finance need to be developed, such as due diligence capacity, alternative financial instruments for debt and insurance products that protect against key risks during development and operations, security arrangements (getting well accustomed to the assignment rights and step-in rights in the project), and waterfall mechanisms. ${ }^{7}$

\section{Strengthen HIDCL and Institutional Investors}

- By increasing institutional capacity. In the near term, twinning arrangements with similar institutions, training and capacity-building project due diligence, and financial structuring are recommended for these institutions to strengthen their capacity to support hydropower development in the country (see table 1). In the medium term, the government could invite a strategic investor that can improve HIDCL's management and project appraisal capacity, and/or pursue a close partnership or combination with a domestic commercial bank. Such partnership with a commercial bank would help HIDCL (i) take advantage of existing financial risk management and governance mechanisms in the commercial bank; (ii) improve the sectoral diversification of the collective portfolio; (iii) overcome some of the regulatory challenges, such as the need for a licensed commercial bank to deploy some of the financing; and (iv) quickly strengthen its capital base. Care must be taken not to put regulatory functions or privileged resources (such as state-backed hedging facilities) within one financing institution, because this would stifle competition among financiers and give an undue advantage to one financier.

- By supporting greater investment from institutional investors. Institutional investors, such as pension funds and insurance companies, have a greater capacity to provide a fixed interest rate and longer term financing; therefore, the entities need to be incentivized to provide further financing to the sector and provided capacity-building exposure

\footnotetext{
${ }^{7} \mathrm{~A}$ cash waterfall mechanism is the basis on which the various entities have the rights on the project cash flows in a project finance transaction. The lenders monitor the project accounts and ensure that payments are made in line with the waterfall mechanism.
} 
similar to domestic commercial banks. The Insurance Board should issue revised investment guidelines for insurance companies, which provide for more investment opportunities and partly address asset-liability mismatches.

\section{Increase Financing from Capital Markets}

By using multilateral guarantees and other risk mitigation mechanisms. It is recommended that the government (i) develop a strategy to mobilize finance from capital markets, using multilateral guarantees, stapled finance structures, ${ }^{8}$ and other risk mitigation mechanisms; and (ii) pilot the strategy in a national priority electricity project.

- By pursuing divestiture/equitization of public entities/assets. As part of the sector restructuring process, it is recommended that the government pursue equitization of NEA generation assets. As a growing number of generation plants developed by NEA subsidiary companies become operational, this strategy can also be extended to them. This would allow the government to release and recycle some of its capital for new T\&D projects, while also providing the opportunity to generate investor and lender interest in operating assets in addition to greenfield IPPs. As part of its equitization/divestiture strategy, it would be advisable for the government to develop a comprehensive asset recycling framework and create an enabling environment for asset recycling tools (figure 5), including stock market modernization and capacity building.

FIGURE 5: Developing an Asset Recycling Framework

\begin{tabular}{|c|c|c|}
\hline Assess & Select the best recycling tool & Create enabling environment \\
\hline $\begin{array}{l}\text { Current operations and } \\
\text { potential for efficiency gains }\end{array}$ & $\begin{array}{l}\text { - Securitizing future } \\
\text { revenues }\end{array}$ & $\begin{array}{l}\text { Improve the regulatory } \\
\text { environment, to include }\end{array}$ \\
\hline $\begin{array}{l}\text { Capacity of the SOE to manage } \\
\text { the asset, given expansion plans }\end{array}$ & $\begin{array}{l}\text { - Selling equity to } \\
\text { strategic investors } \\
\text { - Limited concessions }\end{array}$ & $\begin{array}{l}\text { (ii) accounting, and } \\
\text { (iii) ownership issues that } \\
\text { have hindered asset }\end{array}$ \\
\hline $\begin{array}{l}\text { Debt needs and fiscal capacity } \\
\text { of the SOE, including how to } \\
\text { replace revenue streams in } \\
\text { the event of divestiture }\end{array}$ & $\begin{array}{l}\text { - Infrastructure funds } \\
\text { on the capital } \\
\text { markets }\end{array}$ & recycling. \\
\hline
\end{tabular}

Source: World Bank 2018b.

Note: $\mathrm{SOE}=$ state-owned enterprise.

- By implementing a bond market development roadmap. The government is advised to adopt and implement a bond market development roadmap to enable raising bonds from domestic and foreign markets (that is, diasporas) for the electricity sector. Progress on this agenda will be vital to provide channels for longer term finance in the sector. Among the critical steps to be taken are (i) developing short-term benchmark interest rates, (ii) taking measures to increase liquidity in the longer end of the government bond

\footnotetext{
${ }^{8}$ In a stapled finance structure, the entire procurement process is supported by preapproved financing from development partners and credit enhancement structures in conjunction with the government. It is available with the option of exploring financing outside the preapproved structure, and removes the risk of financing for the bidders.
} 
market, and (iii) plugging regulatory gaps. The roadmap should investigate options for project companies and special-purpose vehicles to issue bonds.

- By reducing transaction costs in the stock market and improving communications. To reduce the cost of owning shares in hydropower projects for local communities and the public, the government is advised to decentralize the current brokerage service by requiring current brokers to offer services at the district level and allowing banks to provide this as an additional service (Rai and Shrestha 2018). The government is advised to prepare and implement a well-designed communications program targeted at retail investors and local communities on the obligations, risks, and opportunities of investing in the capital market and specific hydropower projects.

\subsection{Create an Enabling Environment for Foreign Investment}

The large investment needs of the sector mean that public and local financing alone will not be sufficient, and foreign investment and financing will be needed (table 7). There is a need to mobilize foreign investment and financing for large hydropower projects, utility-scale

TABLE 7: Increase Foreign Investment-Recommended Actions

\begin{tabular}{|c|c|c|}
\hline $\begin{array}{l}\text { Key constraints } \\
\text { (responsibility) }\end{array}$ & Short-term actions & Medium-term actions \\
\hline \multicolumn{3}{|c|}{ Foreign exchange risk } \\
\hline $\begin{array}{l}\text { Risk mitigation mechanisms } \\
\text { (NRB/MOEWRI) }\end{array}$ & $\begin{array}{l}\text { Adopt foreign exchange hedging } \\
\text { guidelines. } \\
\text { Develop appropriate and enabling } \\
\text { guidelines for addressing } \\
\text { the foreign exchange risks in } \\
\text { IPPs with FDI components, } \\
\text { including a relevant review } \\
\text { and recommendations by an } \\
\text { international expert. }\end{array}$ & $\begin{array}{l}\text { Include provisions allowing pass- } \\
\text { through of foreign exchange costs in } \\
\text { electricity tariff guidelines. } \\
\text { Establish a stabilization fund to } \\
\text { smooth tariff increases in the case } \\
\text { of catastrophic devaluation. }\end{array}$ \\
\hline \multicolumn{3}{|c|}{ Foreign investment and financing } \\
\hline $\begin{array}{l}\text { Foreign currency borrowing } \\
\text { (MOF/NRB) }\end{array}$ & $\begin{array}{l}\text { Adopt regulations to facilitate } \\
\text { equitable treatment of foreign } \\
\text { lenders and increase limits on } \\
\text { foreign currency borrowing. }\end{array}$ & $\begin{array}{l}\text { Ease restrictions on foreign } \\
\text { ownership and borrowing by } \\
\text { domestic investors, and broaden } \\
\text { the scope of foreign currency } \\
\text { transactions. } \\
\text { Simplify foreign exchange } \\
\text { repatriation guidelines. }\end{array}$ \\
\hline $\begin{array}{l}\text { One-stop window } \\
\text { (MOF/IBN) }\end{array}$ & $\begin{array}{l}\text { Adopt a framework to manage large } \\
\text { PPP investments through a one-stop } \\
\text { shop. }\end{array}$ & $\begin{array}{l}\text { Use the framework to implement } \\
\text { a national priority project in the } \\
\text { electricity sector. }\end{array}$ \\
\hline $\begin{array}{l}\text { Legal system } \\
\text { (MOLJP) }\end{array}$ & $\begin{array}{l}\text { Implement a capacity-building } \\
\text { program to improve the capacity } \\
\text { of the legal system to manage FDI } \\
\text { issues and disputes. }\end{array}$ & \\
\hline
\end{tabular}

Note: FDI = foreign direct investment; IBN = Investment Board Nepal; IPPs = independent power producers; MOEWRI = Ministry of Energy, Water Resources, and Irrigation; MOF = Ministry of Finance; MOLJP = Ministry of Law, Justice, and Parliamentary Affairs; NEA = Nepal Electricity Authority; NRB = Nepal Rastra Bank; PPP = public-private partnership. 
renewable energy projects, and transmission projects, while closely monitoring the fiscal commitments and contingent liabilities that arise from such arrangements. To increase the role of foreign investors and financiers in the sector, it is recommended that the government undertake policy actions in the following areas.

\section{Manage Foreign Exchange Risk}

- By establishing foreign exchange risk mitigation mechanisms. The risks of foreign exchange movements should be shared among the developer, the end user, and the GoN. The regulator should incorporate provisions in electricity tariff guidelines that allow automatic pass-through of normal foreign exchange devaluation costs in electricity tariffs (USAID 2015). For catastrophic devaluation of currency, it is recommended that the government consider a structural solution, such as establishing a facility like the Petroleum Products Price Stabilization Fund, to bear this risk. Other mitigation mechanisms that the government could consider include implementing rupee-based PPAs, with foreign exchange indexation reflecting the actual foreign exchange risk being passed through, and maximizing local content with partial or full take-out financing after completion, provided this can be done cost effectively. Until Nepal's capital markets are sufficiently developed to support market-based hedging instruments, such as cross-currency swap transactions, the NRB currently plans to establish a hedging facility to reduce foreign currency risks and expects this will help attract foreign finance for projects (see box 3 for discussion on challenges and issues with currently proposed mechanisms).

\section{Facilitate Foreign Investment and Financing}

- By establishing a one-stop window for clearances. To ease and expedite the private investment approval process for large projects, it is recommended that the government implement a single window for obtaining all government clearances for private sector investments of more than 10 billion Nepalese rupees (NPR) (equivalent to US $\$ 88.5$ million). The window should make all policies, laws, and regulations related to FDI available in English and facilitate the efforts of foreign investors to comply with them. Given that past efforts to establish a single window have not been successful, it will be important to learn from experience. The single window must be well resourced and have political support at the highest levels of the government.

- By removing barriers to foreign currency borrowing. To facilitate borrowing in foreign currency, it is recommended that the government address foreign lenders' rights by facilitating the enforcement of collateral through local agent banks, and ease limits on foreign currency borrowing. This measure will enable greater participation by foreign lenders and access by investors to broader and competitively priced sources of funding. To ease restrictions on foreign ownership and borrowing by domestic investors, the government would facilitate foreign exchange-related transactions, including foreign investmentrelated funds transfer and repatriation, and promote the orderly development of a foreign exchange market.

- By strengthening the legal system. To increase foreign investors' confidence, along with harmonizing legal and regulatory inconsistencies and improving the legal framework for FDI, it is recommended that the government implement a capacity-building program to equip the current legal system with experts capable of handling FDI-related issues and disputes. 
- By addressing investors' concerns. To tap the vast amounts of foreign capital, it is also important to respond to investors' concerns about the current-dollar PPA/PDA and the gaps therein, and to consider improving certain aspects for improved bankability and attracting greater FDI. To this end, the sector would benefit from a review of the dollardenominated PPA structure by an international expert, recognizing the country's generation expansion needs and domestic funding and development constraints. 


\section{References}

Asian Development Bank. 2014. Legal and Regulatory Framework Assessment and Recommendation for Public Debt Management and Securities Market in Nepal. Manila.

Citizen's Investment Trust. 2018. Annual Report. Kathmandu. Nepal.

Employee Provident Fund. 2018. Annual Report. Kathmandu. Nepal.

ICIMOD and Niti Foundation. 2016. Benefit Sharing and Sustainable Hydropower: Lessons from Nepal. Kathmandu.

Ministry of Finance. Economic Survey 2018. Kathmandu. Nepal.

Ministry of Energy, Water Resources and Irrigation. 2018. Energy, Water Resources and Irrigation Sector's Current Status and Roadmap for Future. Kathmandu.

Nepal Electricity Authority. 2018a. Financial Viability Action Plan. Kathmandu. Nepal.

Nepal Electricity Authority. 2018b. Annual Report. Kathmandu. Nepal.

Nepal Rastra Bank. 2018a. Monetary Policy for FY2019. Kathmandu. Nepal.

Nepal Rastra Bank.2018b. Annual Report. Kathmandu. Nepal.

Rai, N., and Shrestha, P. 2018. Deconstructing Local Shares: A Critical Examination of the Opportunity for Local Communities to Invest in Hydropower Projects.

Timilsina Govinda, Prakash Raj Sapkota, and Jevgenjis Steinbuks. 2017. "How Much Has Nepal Lost in the Last Decade Due to Load Shedding? An Economic Assessment Using a CGE Model." Policy Research Working Paper WPS 8468, World Bank, Washington, DC.

Upper Tamakoshi Hydropower Limited. 2018. Annual Report. Kathmandu. Nepal.

USAID. 2015. Review of Foreign Exchange Linked Tariffs in Nepal Independent Power Producers. Kathmandu.

USAID. 2016. The role of the Nepali banking, financial services and insurance sector in financing hydropower investment. Kathmandu.

USAID. 2018. Role of Insurance Sector in Nepal Hydropower Development. Kathmandu.

World Bank. 2017a. Climbing Higher: Toward a Middle Income Nepal. The World Bank, Washington D.C.

World Bank Group. 2017b. World Development Report 2017: Governance and the Law. Washington, DC: World Bank.

World Bank. 2018a. Private Participation in Infrastructure Database. Washington D.C.

World Bank. 2018b. Indonesia Infrastructure Assessment Program. Washington D.C. 


\section{mancolity}

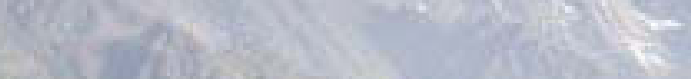

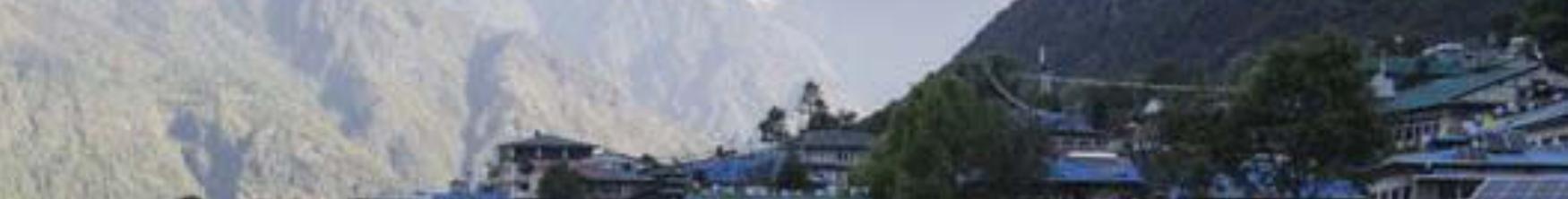

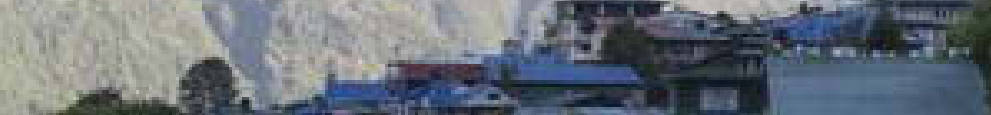

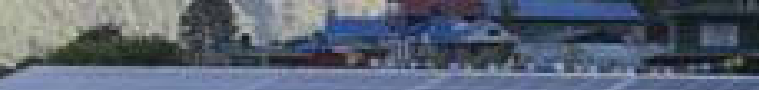

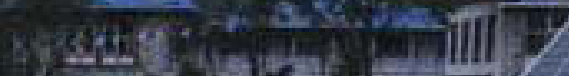
Tyen

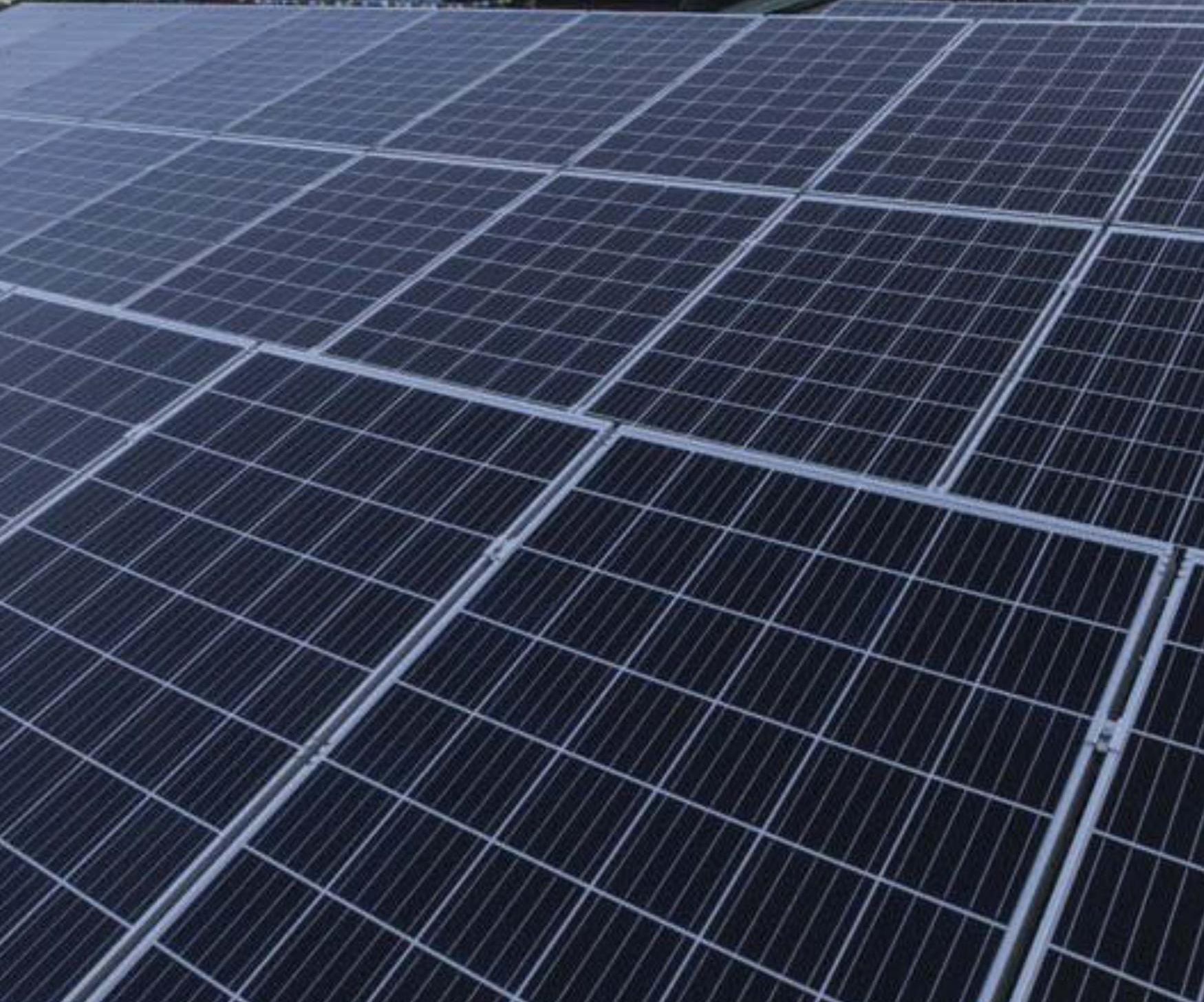




\section{Appendix A: Electricity Sector Overview}

\section{Context and Background}

Nepal faces significant supply constraints in its electricity system. Although Nepal's hydro generation potential is estimated to be more than $40 \mathrm{GW}$, less than one-fortieth, or $1.1 \mathrm{GW}$, of this potential has been developed. The country has added only about $400 \mathrm{MW}$ of hydro generation capacity since 2002 (see box A.1 for key facts). The installed electricity generation capacity was not sufficient to meet the peak demand of about 1,450 MW in 2017 (figure A.1). The shortfall is especially severe in the winter when glacial water flows decrease, reducing the use of the installed capacity by two-thirds. Nepal faced daily power outages of up to 16 hours until late 2016, but increased electricity imports from India and improved management of existing generation have enabled the NEA to resolve load shedding. The T\&D network is aging and stressed, while metering, billing, and collections need to be modernized.

\section{Box A.1: Nepal's Power System}

The total installed capacity in Nepal's power system is 1,073 megawatts (MW), including $562 \mathrm{MW}$ owned by the Nepal Electricity Authority (NEA) and 511 MW owned by the private sector. The demand during the peak hour stands at 1,300 MW and was as high as 1,450 MW in 2017. To meet the current demand, up to $450 \mathrm{MW}$ of electricity is being imported from India. Currently, 2,819 kilometers (km) of 132-kilovolt $(\mathrm{kV})$ transmission lines are in operation. Also, a 78-km, 400-kV, transmission line, a 75-km, 220-kV line, $1,357 \mathrm{~km}$ of $220-\mathrm{kV}$ lines, and 1,357 km of $132-\mathrm{kV}$ transmission lines are under construction. By midMarch 2018, the number of NEA's customers reached 3.5 million, of which 94 percent are domestic customers consuming 41.9 percent of the total supply, 1.4 percent are industrial customers consuming 35.6 percent of total supply, and 4.6 percent are other customers consuming 22.5 percent of the total supply. In addition, 281 community organizations are serving 500,000 customers, and the Butwal Power Company is supplying electricity to 50,000 customers in the remote districts of Syanja, Palpa, Arghakhachi, and Pyuthan.

Most households and businesses in Nepal do not have access to adequate and reliable electricity service. While 95 percent of the population is estimated to have access to grid and off-grid electricity, the per capita electricity consumption of 177 kilowatt-hours $(\mathrm{kWh})$ per year is one-twentieth of the global average and one-fifth of the per capita electricity consumption in South Asia (figures A.2 and A.3). Nepal relies overwhelmingly on traditional biomass and imported petroleum to meet its energy needs, which constitute 80 percent and 12 percent of energy consumption, respectively. Electricity constitutes less than 5 percent of energy consumption, despite the country's large hydro generation potential. 
FIGURE A.1: Peak Demand versus Electricity Supply, 1997-2017

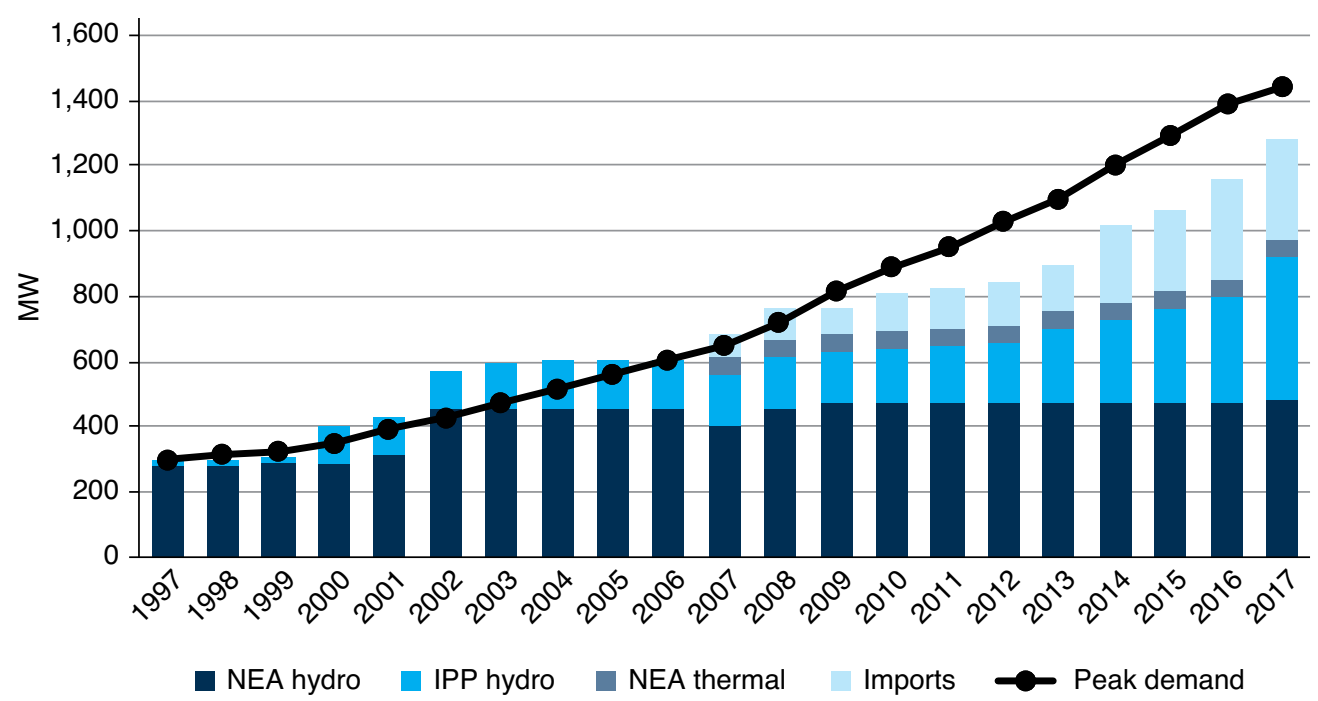

Source: NEA.

Note: IPP = independent power producer; MW = megawatts; NEA = Nepal Electricity Authority.

FIGURE A.2: Electricity Access (\%)

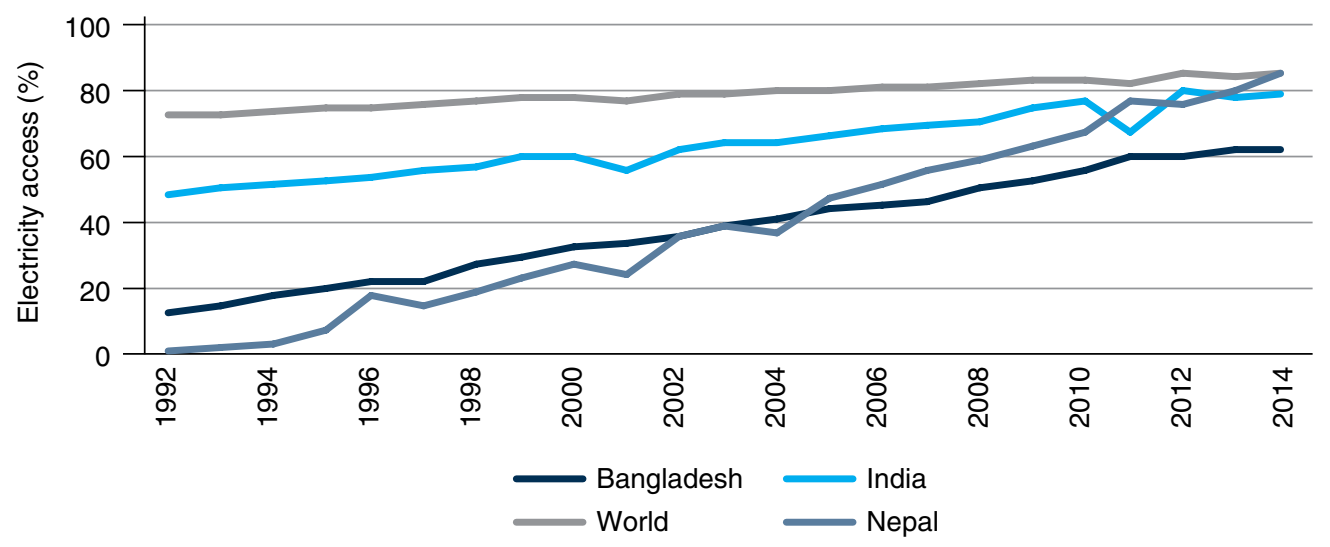

Source: World Development Indicators 2018. 
FIGURE A.3: Per Capita Electricity Consumption

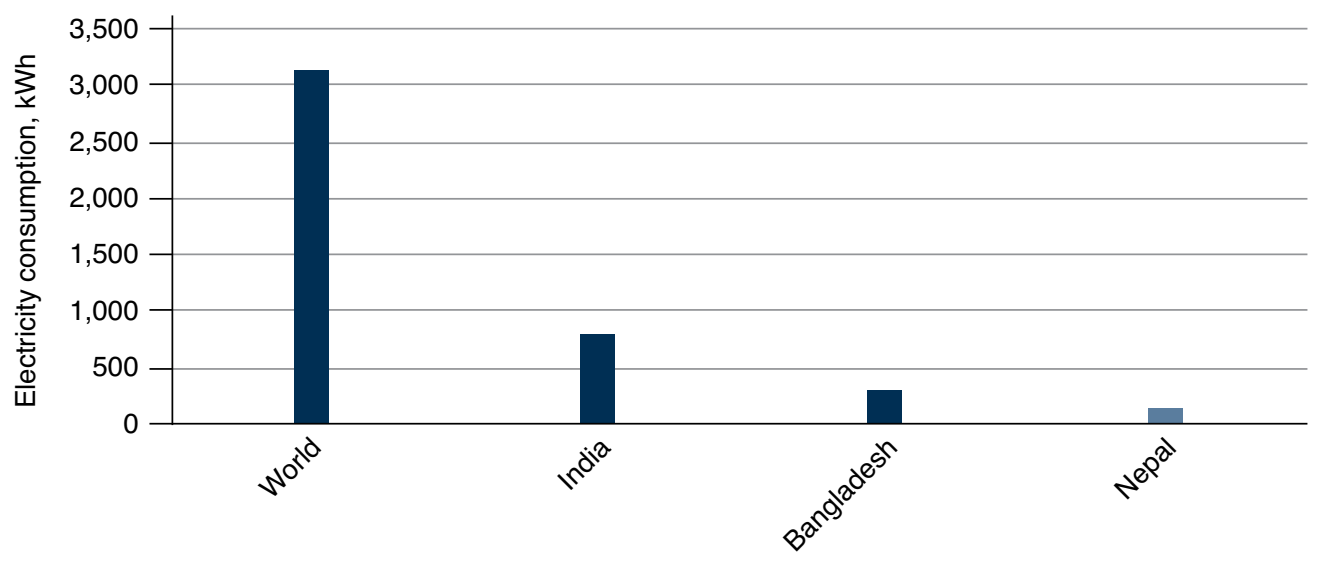

Source: World Development Indicators 2018.

Note: $\mathrm{kWh}=$ kilowatt-hour.

This lack of access has adversely affected the country's economic performance. Two-thirds of Nepal's firms identify electricity as a major constraint to doing business in Nepal. Commercial and industrial consumers must rely on expensive diesel generators. The economic loss from load shedding is estimated to be as high as US\$1.6 billion per year during 2008-16. The high cost of power has severely weakened their productivity, competitiveness, and growth. The lack of job opportunities has pushed more than 5 million Nepali laborers to work overseas. Agriculture is the largest contributing sector to the GDP, but its productivity is also constrained by the lack of electricity for irrigation.

Substantial generation capacity is under development but is facing delays in implementation. The NEA has signed PPAs for 244 hydroelectric projects with total installed capacity of 4,138 MW, of which 73 projects with a total installed capacity of $511 \mathrm{MW}$ have started commercial electricity generation and are connected to the national grid. Most hydropower plants under construction are experiencing delays caused by external shocks, such as the 2015 earthquakes, trade blockade with India, and weak implementation capacity. Timely commissioning of the planned projects could lead to surplus generation in the summer months. The electricity shortage in the dry season on the other hand is expected to continue in the medium term and will need to be mitigated through electricity imports from India.

Nepal has been increasingly relying on electricity imports from India to reduce the electricity shortage in the country. The share of electricity imported from India increased to 35 percent in FY2017 from less than 10 percent in FY2006. The increase in electricity trade was made possible by the completion of a key interconnection between Muzzafarpur in India and Dhalkebar in Nepal, which facilitated about $300 \mathrm{MW}$ of imports from India in FY2017. The cost of imports from India (NPR 5-9/kWh) is projected to be lower than expensive storage projects in Nepal (>NPR 10/kWh), indicating that imports can be a more economic option for meeting demand in the dry season. Given the prospect of surplus electricity in the wet season in Nepal from FY2020, there will be a strong economic rationale for Nepal to export to India in the wet season. The difference in the daily load curve between northern India and Nepal will also provide opportunities for optimizing load-generation balance in the region. Overall, electricity trade with 
India represents a win-win option for Nepal to improve the reliability of its electricity system and meet its electricity requirements cost effectively.

The development of large export-oriented hydropower projects has so far failed to materialize despite interest from reputed international developers. The government has signed PDAs with several large export-oriented projects; however, despite years of effort, none of these projects has yet reached financial closure. ${ }^{9}$ Nonetheless, the potential for export to India and neighbors, such as Bangladesh, remains, and the export could take place once the appropriate political as well as enabling institutional and regulatory frameworks to facilitate electricity trade with neighbors are in place.

Investments must increase substantially to meet the medium-term needs of the sector. Investment in the sector needed to meet the electricity demand in the country is estimated to be at least US $\$ 1.3$ billion per year through 2030 . Since domestic resources will not be sufficient for meeting the required investment, the government will need to find ways to mobilize foreign investments together with government and local private investment.

\section{Issues and Challenges}

The creditworthiness of the vertically integrated utility NEA is weak (see box A.2 for list of key electricity sector institutions). Almost a quarter of the electricity is lost because of technical and nontechnical losses, unfairly increasing the cost of electricity to paying consumers. Electricity tariffs have been set by the government through the Electricity Tariff Fixation Commission,

\section{Box A.2: Key Electricity Sector Institutions Ministry of Energy Water Resources and Irrigation (MOEWRI):}

This line ministry has primary jurisdiction over the power sector and is responsible for the development of water resources in Nepal.

National Planning Commission: The commission is the apex advisory body of the government of Nepal (GoN) for formulating a national vision, periodic plans, and policies for development.

Department of Electricity Development: The department is responsible for assisting MOEWRI in the implementation of overall government policies related to the power/electricity sector. It facilitates the private sector's participation in the power sector by providing "one-stop" service and license to power projects.

Nepal Electricity Authority: As a vertically integrated utility within the GoN, the NEA is responsible for the generation, transmission, and distribution of electricity in the country.

Water and Energy Commission Secretariat: Established by the GoN in 1975, the primary responsibility of the secretariat is to assist the GoN, different ministries relating to water resources, and other related agencies in the formulation of policies and planning of projects in the water and energy resources sector.

Investment Board Nepal: The IBN was created in 2011 by the Investment Board Nepal Act. The IBN was formed to promote economic development in Nepal by creating an investment-friendly environment. It does so by mobilizing and managing public-private partnerships and domestic and foreign private investment in such sectors as hydropower, chemical fertilizers, and integrated solid waste management.

\footnotetext{
${ }^{9}$ Projects for which the PDA has already been signed with the GoN include $900 \mathrm{MW}$ in Arun and $900 \mathrm{MW}$ in Upper Karnali.
} 
and tariff increases have been highly irregular. NEA losses in 2016 (US\$82.7 million) were equal to 0.5 percent of GDP. Cumulative losses of the NEA since 2008 (US\$643 million) are equal to 3 percent of GDP. NEA is unable to serve its debts or generate the financing required to invest in power system infrastructure. NEA's poor creditworthiness is one of the major difficulties for IPPs in raising project financing against PPAs. The NEA faces a growing conflict of interest in its relationship with the IPPs because of its ownership of electricity generation and its control over transmission and dispatch. For the first time in 10 years, the NEA began operating at a profit in FY2016-17 because of a 14 percent increase in tariffs and implementation of a financial restructuring plan. Yet a sustained focus on increasing revenue, reducing system losses, and financing costs will be needed in the coming years to enable the NEA to meet its PPA obligations and maintain robust financial health.

The electricity sector's legal and institutional framework is weak. While successive governments in Nepal have expressed a commitment to attract private sector investment, progress in establishing an enabling environment for large private investments has been limited. Attracting and retaining private investment requires mechanisms for sharing risks; the provision of common infrastructure, such as transmission corridors and roads; streamlined procedures; regulatory improvements; and structural reforms. The government has failed to update the legal and institutional framework that was set up in the early 1990s to institute such arrangements (see box A.3 for the list of electricity sector legislation and policies). Electricity agencies continue to have overlapping roles, unclear mandates, and multiple roles. The Electricity Act has not been updated since 1992, and does not provide a framework to allow IPPs to exploit the surplus generation in the system through exports and trade. The sector does not have an independent and fully empowered regulatory authority. Given the NEA's ownership of generation and its control over transmission and dispatch, the current institutional framework does not provide a level playing field in the sector to IPPs.

There are major challenges to mobilizing domestic financing for hydropower development. There continues to be keen interest among domestic investors and financial institutions to develop hydropower projects. However, the ability of developers to access this financing remains limited because of (i) the elevated risk perception of hydro among lenders as a result of the NEA's poor creditworthiness, (ii) the lack of availability of long-tenor loans, (iii) the poor capacity of financing institutions to appraise hydropower projects, and (iv) the unavailability of nonrecourse project finance in the sector.

The enabling condition to attract foreign investment to the sector is weak. Almost all of the new capacity expected to come online in the next five years is being developed by either subsidiaries of the vertically integrated utility NEA or small domestic IPPs with take-or-pay PPAs with the NEA. Foreign IPPs have not achieved progress, given the absence of dollar-denominated PPAs and country and sector risks. While Nepal's first two IPPs were developed with foreign investment in the 1990s, the NEA had not signed further PPAs with foreign IPPs until 2017. The PPA rates of these two IPPs-Himal Khimti and Bhotekoshi-have escalated significantly since the mid-1990s and are now three times higher (US\$0.14 and US $\$ 0.11$, respectively) than the PPA rate the NEA has with domestic IPPs in the wet season (US\$0.04). Negotiations with foreign IPPs have on many occasions stalled because of unclear PPA guidelines and the NEA's unwillingness to bear foreign exchange risks of dollar-denominated PPAs. 


\section{Box A.3: Legal and Regulatory Framework in the Energy Sector}

At present, various legal instruments for the management and use of energy resources exist and are under enforcement, including Nepal Electricity Authority Act 1984, Water Resources Act 1992, Electricity Act 1992, Environment Protection Act 1997, Electricity Theft Control Act 2002, Water Resources Strategy 2002, the Hydropower Development Policy 2001, National Water Plan 2005, and Rural Energy Policy 2006. The key laws are briefly described as follows:

- Nepal Electricity Authority Act 1984: This act provides for the establishment of the NEA to oversee power supply by generating, transmitting, and distributing electricity in an efficient, reliable, and convenient manner.

- Electricity Act 1992: The laws relating to the survey, generation, transmission, and distribution of electricity, as well as standardization and safeguard issues relating to electricity services, come under this act. This act introduced incentives for private investment through tax holidays and customs duty exemption and provides a legal basis for private participation in the generation, transmission, and distribution business.

- Water Resources Act 1992: This umbrella act governing water resource management declares the order of priority of water use and vests ownership of water in the state, provides for the formation of water user associations, establishes a system of licensing, and prohibits water pollution.

- Electricity Theft Control Act 2002: The act defines electricity theft in its different forms and provides penalty mechanisms to reduce electricity theft in the country.

- Hydropower Development Policy 2001: This policy introduced a competitive environment for electricity development with the setup of an independent regulatory body and unbundling of the NEA. It also emphasized bilateral and regional energy cooperation.

- Investment Board Nepal Act 2011: Apart from large infrastructure projects, such as roads and airports, large hydropower projects generating more than 500 megawatts also come under the jurisdiction of the IBN. The objective of this institution is to create an environment for investment in infrastructure development and to manage and mobilize investment of public-private partnerships and national as well as foreign private investors. The IBN functions directly under the chairmanship of the prime minister of Nepal.

- ERC Act 2017: The act defines the role of the Electricity Regulatory Commission, which (1) determines tariffs and regulates the sale and purchase of electricity, (2) supports the establishment of a wholsale electricity market, (3) introduces transparency and competition in the electricity market, and (4) protects the interest of consumers.

Despite the progress made over the past few years, sector-specific guidelines on environmental and social issues still require improvement. Electricity projects implemented during the last decade were significantly delayed because of issues related to land acquisition, environmental clearance, resettlement, transmission right-of-way compensation, and benefit-sharing issues. Inadequate guidance as well as weak and inefficient review, approval, and oversight processes within the government led to poor management of environmental and social issues in projects. Adequate investments and timely completion of T\&D lines to support the evacuation of power from new hydro generation plants are an ongoing challenge.

Investment decisions in the sector are not sufficiently informed by a formal planning process. Investments in the sector are guided by the periodic plans of the National Planning Commission, which lay out the three-year targets for various sectors, including the power sector. Investments to meet these targets are selected on a project-by-project basis without adequate 
consideration of the technical and economic merits of the projects and without sufficient coordination with other investment decisions. The use of formal sector plans (covering, load demand, generation, transmission, and distribution) and river basin plans to inform the priority order of investments is absent. There is no coordination between access efforts through grid extension and off-grid renewable energy technologies. There is a need to strengthen the hydropower licensing process by moving from a developer-driven approach to an open, transparent, and efficient licensing process based on basin-wide hydropower development planning.

Local technical capacity to develop large electricity sector projects, including storage projects, is inadequate. There is insufficient local capacity to develop large hydropower projects and transmission lines and substations with voltages higher than $220 \mathrm{kV}$. The NEA and domestic IPPs lack the know-how and capacity to develop large storage hydro projects with complex technical, social, and environmental requirements. A lack of preparation of an adequate number of projects in line with international standards is also one of the major barriers in catalyzing expected foreign investment and financing. Inadequate capacity within public agencies has generated long delays in the review and approval process when the technical preparation work is submitted from private developers.

The transition to the federal structure under Nepal's new constitution will add complexity to the sector. Electricity is defined as a concurrent subject in Nepal's new constitution, implying that responsibilities in the sector would be shared between the central and provincial governments. While a clear definition of responsibilities of central- and provincial-level governments is still pending, provincial governments are expected to have a role in electricity distribution and generation. 


\section{Appendix B: Financial Analysis of Nepal Electricity Authority}

\section{Current Financial Performance}

The NEA became profitable in FY2017 despite headwinds. An increase of about 14 percent in the average billing rate in FY2017, coupled with reduction in system losses from 25.8 percent to 22.9 percent and implementation of the NEA financial restructuring plan (Prior Action 1), helped the NEA become a profitable entity. The NEA posted a net profit of NPR 1.5 billion (US $\$ 14$ million) in FY2017 (figure B.1). The costs from T\&D losses fell by 11 percent (figure B.2). The almost 30 percent increase in sales was attributable to reduced load-shedding hours for industries and commercial setups in the Kathmandu and Pokhara regions, in addition to a steady growth in the number of consumers.

FIGURE B.1: Revenue and Profit (NPR, million)

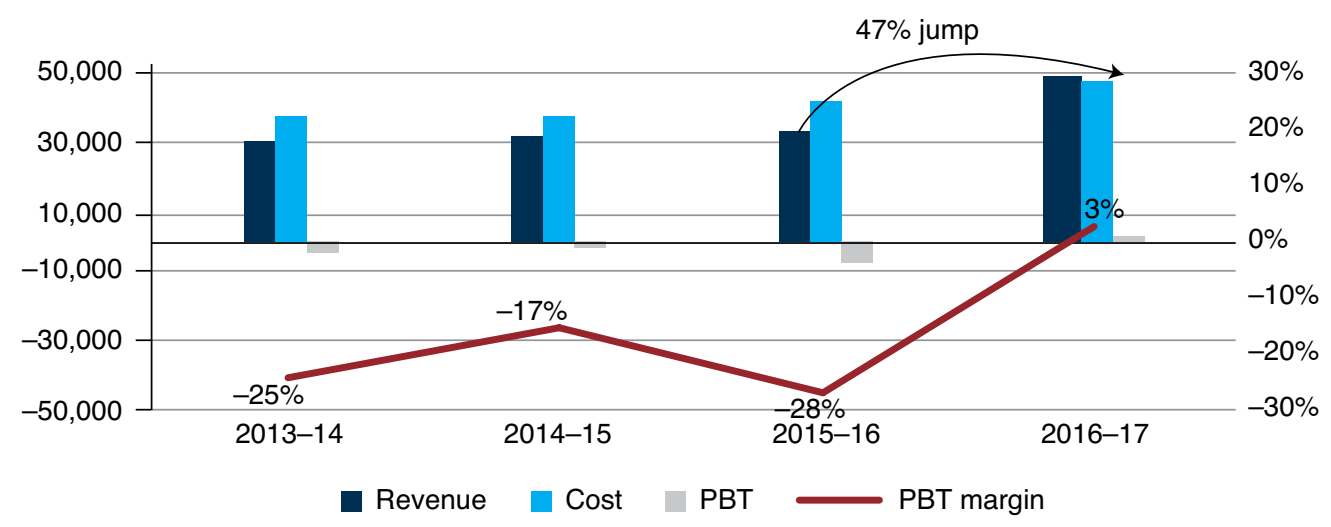

Source: NEA FVAP 2018.

Note: NPR = Nepalese rupee; PBT = profit before tax.

Before FY2017, the NEA had posted 10 consecutive years of losses due to below-cost retail electricity tariffs and high system losses. T\&D losses averaged more than 25 percent in this period. There was no increase in electricity tariffs between 2001 and 2012 and then again until 2016. By FY2016, the net accumulated losses had reached NPR 69.4 billion (US\$643 million), or 16 percent of the total asset size.

The NEA financial restructuring plan was helpful in improving the NEA's finances. The GoN converted its NPR 14 billion (US\$130 million) loan to the NEA into equity and added another NPR 
FIGURE B.2: Cost Structure FY2017 (NPR per kWh)

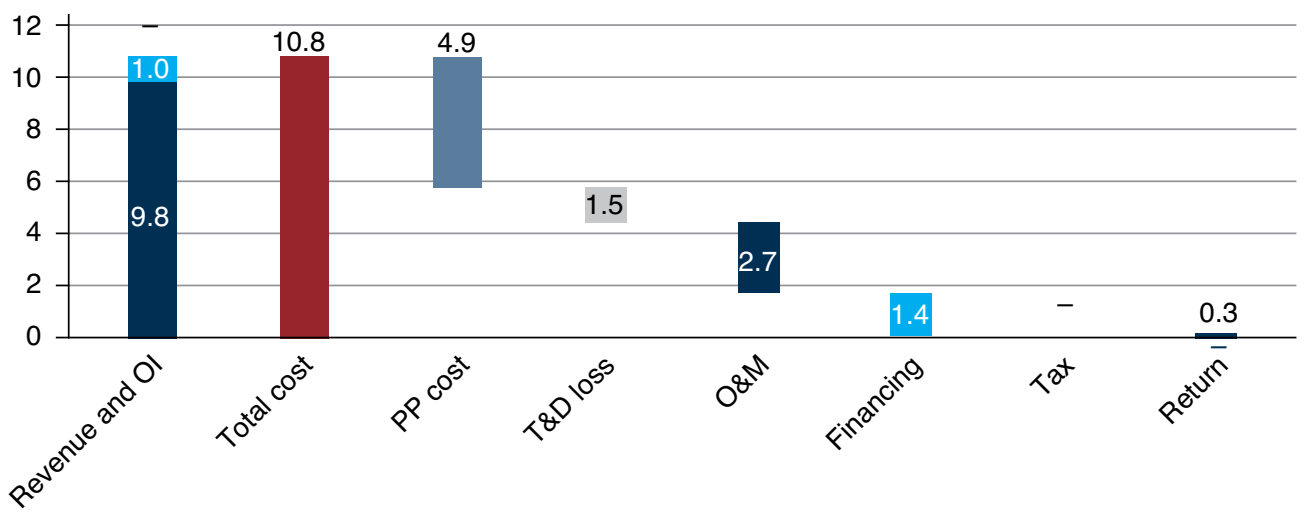

Source: NEA FVAP 2018.

Note: $-=$ not available; $\mathrm{kWh}=$ kilowatt-hour; NPR = Nepalese rupee; $\mathrm{OI}=$ operating income; $\mathrm{O} \& \mathrm{M}=$ operation and maintenance; $\mathrm{PP}=$ power purchase; $\mathrm{T} \& \mathrm{D}=$ transmission and distribution.

10 billion (US $\$ 100$ million) as new equity, leading to an improvement in the debt-to-equity ratio from 1.9 in FY2016 to 1.3 in FY2017. The NEA's interest expenses were reduced by 31 percent from FY2016 to FY2017, and its interest service coverage ratio and current ratio improved from -0.8 and 0.5 in FY2016 to 1.75 and 0.6, respectively, in FY2017. (See figures B.3, B.4, and B.5 for more information on the evolution of the NEA's energy, consumer, sales, revenue mix, and cost of power.)

FIGURE B.3: Energy Mix (\%)

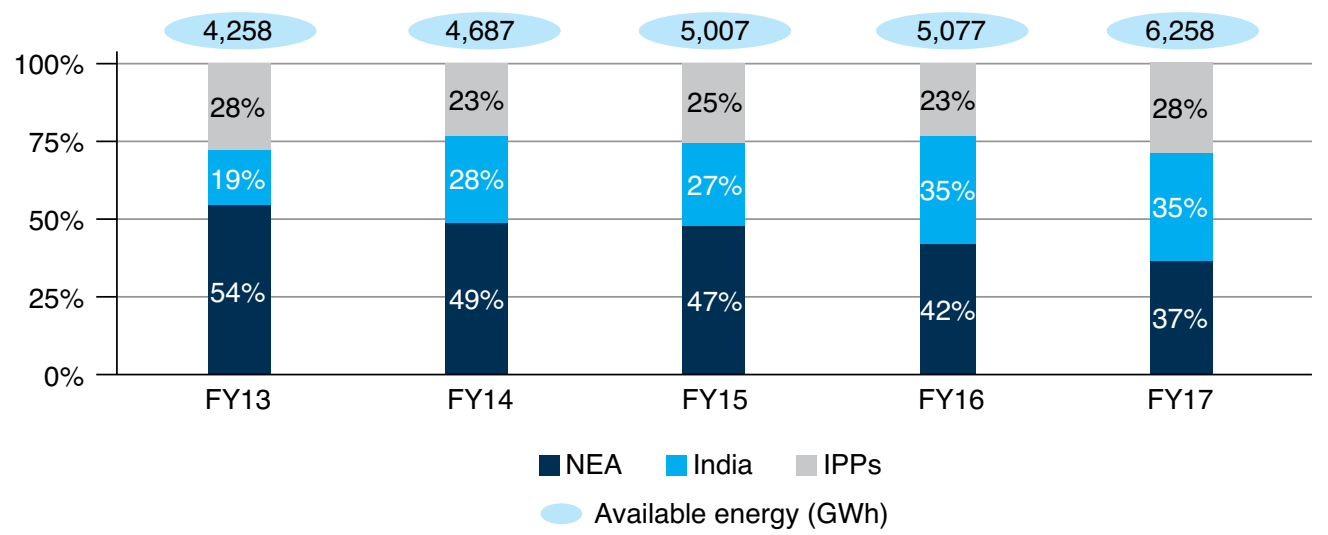

Source: NEA FVAP 2018.

Note: GWh = gigawatt-hour; IPPs = independent power producers; NEA = Nepal Electricity Authority.

\section{The NEA's Financial Outlook}

The NEA's financial obligations are set to increase significantly in the next five years as several new IPPs with take-or-pay contracts come online. The NEA's power purchase cost is expected to increase threefold, from US $\$ 272$ million to US\$860, between FY2018 and FY2022. 
FIGURE B.4: Average Cost of Power (NPR per kWh)

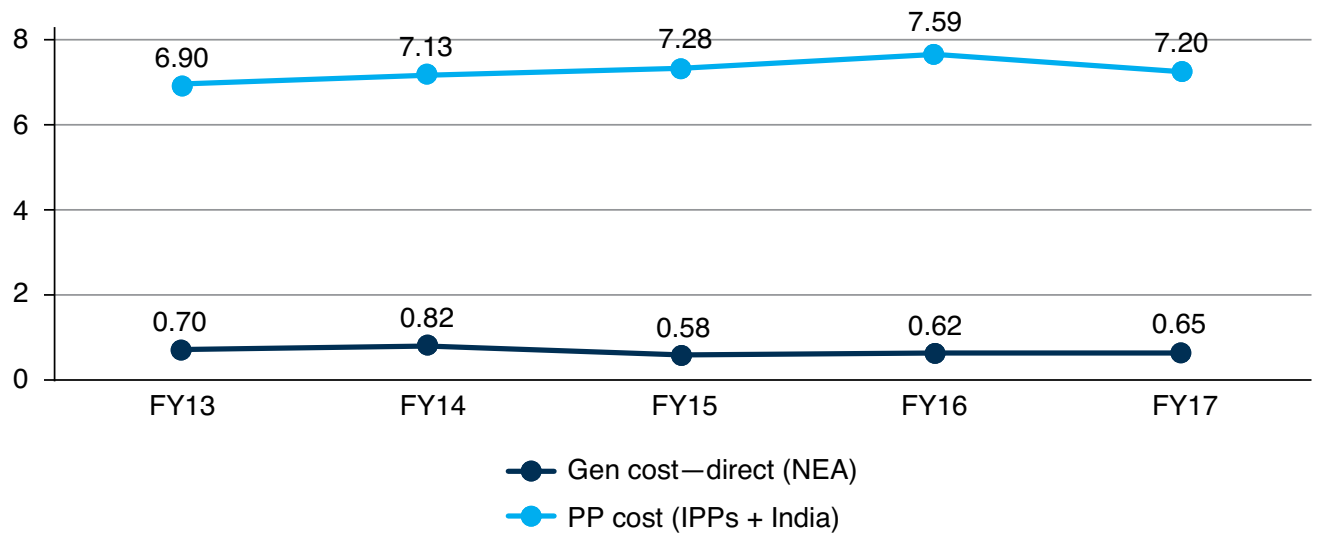

Source: NEA FVAP 2018.

Note: gen = generation; kWh = kilowatt-hour; IPPs = independent power producers; NEA = Nepal Electricity Authority; $\mathrm{NPR}=$ Nepalese rupee; $\mathrm{PP}=$ power purchase.

FIGURE B.5: Consumer, Sales, and Revenue Mix

\section{Consumer Mix}

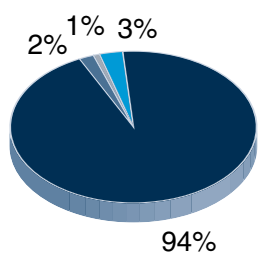

Domestic
Sales Mix

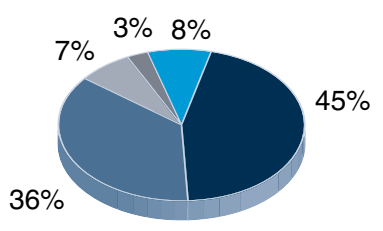

Industrial

Commercial

Noncommercial

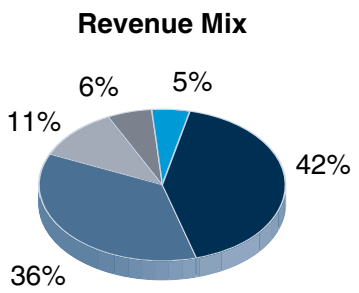

Others

Source: NEA FVAP 2018.

Further the NEA has planned a capital expenditure of US $\$ 2.7$ billion between FY2018 and FY2022 (figures B.6 and B.7). The depreciation expense and interest expense on long-term loans are also projected to increase consequently in the next five years, in line with planned capital expenditure. $0 \& M$ expenses are projected to increase at a rate of 8 percent, in line with inflation rates.

Under the BAU scenario, the NEA's average cost of supply (ACoS) is projected to increase significantly. The BAU scenario assumes that the historical levels of T\&D losses would be maintained, and that the NEA would net out its electricity exports in the wet season with electricity imports in the dry season through energy banking with its neighbors. There would, however, be no export of surplus electricity beyond this. The NEA's ACoS under this scenario is projected to increase from US\$0.097 (NPR 10.1/kWh) per unit in FY2017 to US\$0.156 (NPR 16.2/kWh) per unit in FY2022.

The implementation of the NEA's financial sustainability framework will help moderate the increase in the NEA's cost. As part of its financial sustainability framework, the NEA is targeting to reduce T\&D losses from 22.8 percent in FY2017 to 15.3 percent in FY2022 and net out its electricity exports in the wet season with electricity imports in the dry season through 
energy banking with its neighbors. Likewise, it expects to find markets for 90 percent of the surplus electricity from its electricity generation plants and take-or-pay contracts in neighboring countries. Under the reform scenario consisting of the successful implementation of the financial sustainability framework, the NEA's ACoS is projected to increase from US $\$ 0.094$ per unit (NPR $9.8 / \mathrm{kWh}$ ) in FY2017 to US $\$ 0.106$ per unit (NPR 11/kWh) in FY2022. The projected income statement, cash flow statement, balance sheet, and financial ratios of the NEA over FY2018-22 for the reform scenario are presented in tables B.1-B.5.

FIGURE B.6: Expenditure Projections (NPR billion)

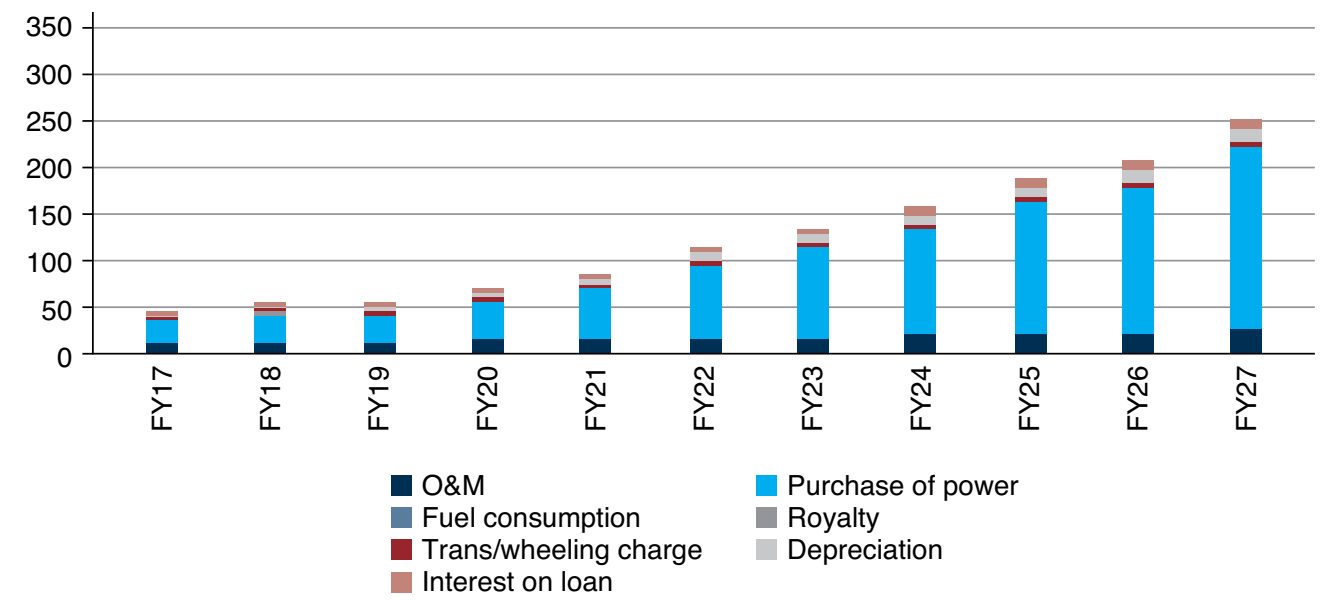

Source: NEA Financial Viability Action Plan 2018.

Note: FY = fiscal year; NEA = Nepal Electricity Authority; NPR = Nepalese rupee; O\&M = operation and maintenance; trans $=$ transportation.

FIGURE B.7: Growth Rate of NEA Expenditure (\%)

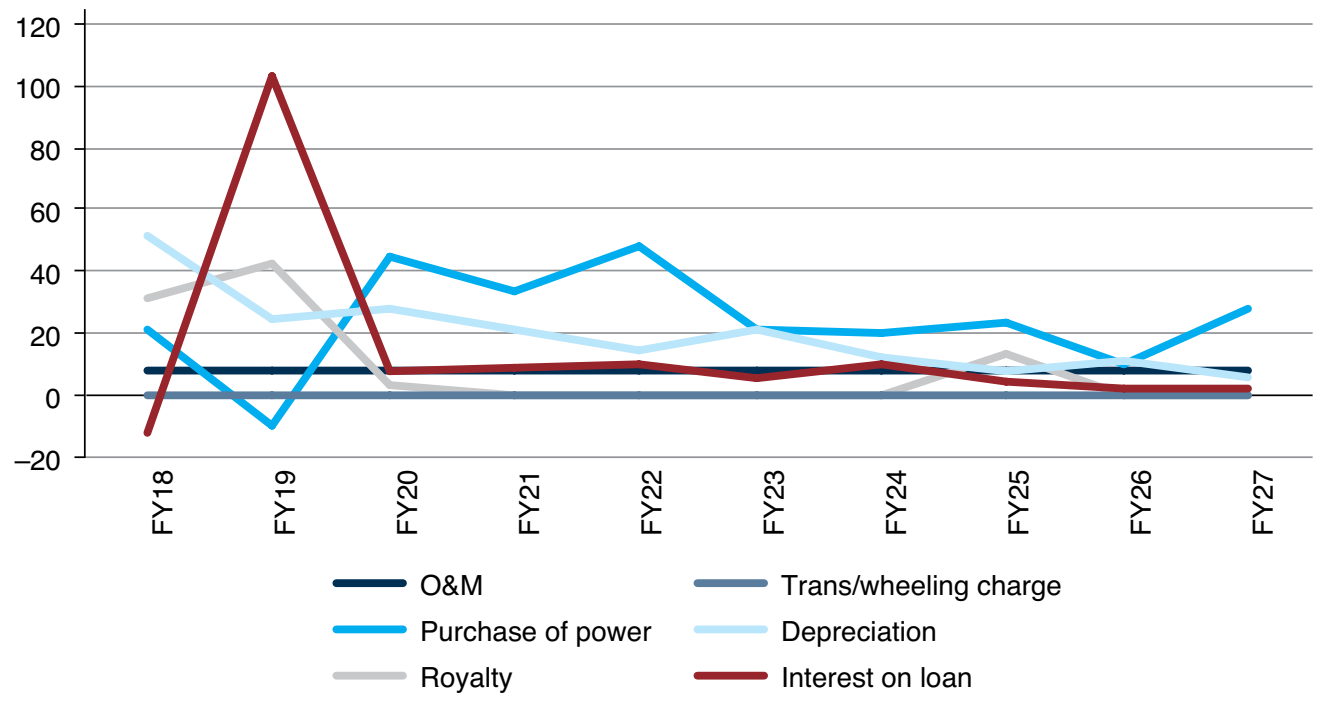

Source: NEA Financial Viability Action Plan 2018.

Note: FY = fiscal year; NEA = Nepal Electricity Authority; NPR = Nepalese rupee; O\&M = operation and maintenance; trans $=$ transportation. 
TABLE B.1: ACoS in Business as Usual and Reform Scenarios (NPR per kWh)

\begin{tabular}{l|c|c|c|c|c|}
\multicolumn{1}{c|}{ Scenarios } & FY2018 & FY2019 & FY2020 & FY2021 & FY2022 \\
\hline ACoS (business as usual scenario) & 10.1 & 11.2 & 12.6 & 13.6 & 16.2 \\
\hline ACoS (reform scenario) & 9.8 & 10.4 & 10.4 & 10.4 & 11.0 \\
\hline
\end{tabular}

Note: $\mathrm{ACOS}=$ average cost of supply; FY = fiscal year; $\mathrm{kWh}=$ kilowatt-hour; NPR = Nepalese rupee.

TABLE B.2: Projected Income Statement of the NEA under the Reform Scenario (NPR, millions)

\begin{tabular}{|c|c|c|c|c|c|}
\hline Income sources and expenditures & FY2018 & FY2019 & FY2020 & FY2021 & FY2022 \\
\hline Revenue from sale of power & 57,289 & 74,858 & 88,785 & 120,013 & 137,419 \\
\hline Revenue from export to India & - & 583 & 4,518 & 8,041 & 16,649 \\
\hline Revenue subsidy & - & - & - & - & - \\
\hline Other income & 5,092 & 5,601 & 6,161 & 6,777 & 7,455 \\
\hline Dividend income & 162 & 162 & 857 & 1,115 & 1,401 \\
\hline \multicolumn{6}{|l|}{ Expenditure } \\
\hline O\&M cost & 14,010 & 15,131 & 16,341 & 17,649 & 19,061 \\
\hline Employee expenses & $(9,576)$ & 10,342 & 11,170 & 12,063 & 13,028 \\
\hline Rehabilitation \& maintenance & $(2,495)$ & 2,695 & 2,910 & 3,143 & 3,395 \\
\hline Administrative \& general & $(1,939)$ & 2,094 & 2,262 & 2,443 & 2,638 \\
\hline Purchase of power & 32,342 & 30,487 & 46,086 & 62,421 & 92,580 \\
\hline Fuel consumption & - & - & - & - & - \\
\hline Royalty & 1,271 & 1,806 & 1,865 & 1,865 & 1,865 \\
\hline Transmission/wheeling charge & 1,017 & 1,017 & 1,017 & 1,017 & 1,017 \\
\hline Total & 48,640 & 48,442 & 65,310 & 82,952 & 114,523 \\
\hline PBITDA & 13,903 & 32,763 & 35,012 & 52,994 & 48,401 \\
\hline Depreciation & 5,453 & 7,003 & 9,611 & 12,173 & 14,557 \\
\hline PBIT & 8,451 & 25,760 & 25,401 & 40,821 & 33,844 \\
\hline Interest on loan & 3,078 & 6,061 & 6,550 & 7,354 & 8,227 \\
\hline Interest on working capital loan & 701 & 932 & 1,020 & 1,309 & 1,358 \\
\hline Gain/(loss) on foreign exchange & - & 1 & 4 & 69 & 206 \\
\hline Interest on cash deficit loan & - & - & - & - & - \\
\hline Profits before tax & 4,672 & 18,766 & 17,828 & 32,090 & 24,053 \\
\hline Tax payable & 1,168 & 4,691 & 4,457 & 8,022 & 6,013 \\
\hline Profit after tax & 3,504 & 14,074 & 13,371 & 24,067 & 18,040 \\
\hline
\end{tabular}

Note: $-=$ not available; FY = fiscal year; NPR = Nepalese rupee; O\&M = operation and maintenance; PBIT = profit before interest and taxes; PBITDA = profit before interest, taxes, depreciation, and amortization. 
TABLE B.3: Projected Cash Flow Statement of the NEA under the Reform Scenario (NPR, million)

\begin{tabular}{|c|c|c|c|c|c|}
\hline Cash flows & FY2018 & FY2019 & FY2020 & FY2021 & FY2022 \\
\hline Revenue & 57,289 & 74,858 & 88,785 & 120,013 & 137,419 \\
\hline Revenue from export to India & - & 583 & 4,518 & 8,041 & 16,649 \\
\hline Revenue subsidy & - & - & - & - & - \\
\hline Other income & 5,092 & 5,601 & 6,161 & 6,777 & 7,455 \\
\hline Dividend income & 162 & 162 & 857 & 1,115 & 1,401 \\
\hline O\&M cost & $(14,010)$ & $(15,131)$ & $(16,341)$ & $(17,649)$ & $(19,061)$ \\
\hline Purchase of power & $(32,342)$ & $(30,487)$ & $(46,086)$ & $(62,421)$ & $(92,580)$ \\
\hline Fuel consumption & - & - & - & - & - \\
\hline Royalty & $(1,271)$ & $(1,806)$ & $(1,865)$ & $(1,865)$ & $(1,865)$ \\
\hline Transmission/wheeling charge & $(1,017)$ & $(1,017)$ & $(1,017)$ & $(1,017)$ & $(1,017)$ \\
\hline Taxes & $(1,168)$ & $(4,691)$ & $(4,457)$ & $(8,022)$ & $(6,013)$ \\
\hline Change in current assets and liabilities & $(10,012)$ & $(3,301)$ & $(1,255)$ & $(4,127)$ & $(710)$ \\
\hline Cash flow from operating activities & 2,723 & 24,771 & 29,300 & 40,844 & 41,677 \\
\hline Change in investments & $(1,897)$ & $(4,810)$ & $(7,633)$ & $(10,959)$ & $(16,931)$ \\
\hline Capital expenditure & $(24,891)$ & $(79,543)$ & $(83,956)$ & $(79,897)$ & $(78,159)$ \\
\hline Cash flow from investment activities & $(26,788)$ & $(84,354)$ & $(91,589)$ & $(90,856)$ & $(95,090)$ \\
\hline Debt & 14,990 & 48,466 & 51,994 & 48,754 & 47,358 \\
\hline Equity & 7,859 & 23,448 & 23,890 & 23,481 & 23,309 \\
\hline Cash deficit loan & - & - & - & - & - \\
\hline Debt repayment & $(2,808)$ & $(5,895)$ & $(6,632)$ & $(8,166)$ & $(10,577)$ \\
\hline Cash deficit loan repayment & - & - & - & - & - \\
\hline Increase in working capital loan & 7,009 & 2,310 & 879 & 2,889 & 497 \\
\hline Interest on debt & $(3,078)$ & $(6,061)$ & $(6,550)$ & $(7,354)$ & $(8,227)$ \\
\hline Interest on working capital loan & $(701)$ & (932) & $(1,020)$ & $(1,309)$ & $(1,358)$ \\
\hline Gain/(loss) on foreign exchange & - & (1) & (4) & (69) & $(206)$ \\
\hline Interest on cash deficit loan & - & - & - & - & - \\
\hline Cash flow from financing activities & 23,272 & 61,335 & 62,557 & 58,226 & 50,797 \\
\hline \multicolumn{6}{|l|}{ Cash schedule } \\
\hline Opening cash balance & 24,824 & 24,031 & 25,783 & 26,051 & 34,265 \\
\hline Cash generated during the year & $(793)$ & 1,752 & 268 & 8,214 & $(2,616)$ \\
\hline Closing cash balance & 24,031 & 25,783 & 26,051 & 34,265 & 31,649 \\
\hline
\end{tabular}

Note: $-=$ not available; FY = fiscal year; NPR = Nepalese rupee; O\&M = operation and maintenance. 
TABLE B.4: Projected Balance Statement of the NEA under the Reform Scenario (NPR, million)

\begin{tabular}{|c|c|c|c|c|c|}
\hline Assets and liabilities & FY2018 & FY2019 & FY2020 & FY2021 & FY2022 \\
\hline Gross fixed assets & 201,705 & 250,764 & 330,188 & 406,482 & 476,895 \\
\hline Accumulated depreciation & 55,667 & 62,670 & 72,281 & 84,454 & 99,010 \\
\hline Net fixed assets & 146,038 & 188,094 & 257,908 & 322,029 & 377,885 \\
\hline Capital work in progress & 44,090 & 74,574 & 79,106 & 82,709 & 90,455 \\
\hline Investments & 27,657 & 32,467 & 40,101 & 51,059 & 67,991 \\
\hline Current assets & 36,187 & 39,335 & 41,862 & 47,342 & 50,531 \\
\hline Cash and bank balance & 24,031 & 25,783 & 26,051 & 34,265 & 31,649 \\
\hline Total assets & 278,003 & 360,254 & 445,027 & 537,405 & 618,512 \\
\hline Equity & 90,372 & 113,820 & 137,710 & 161,190 & 184,500 \\
\hline Reserve and surplus & $(22,873)$ & $(8,799)$ & 4,572 & 28,639 & 46,679 \\
\hline Non-current liabilities & 693 & 693 & 693 & 693 & 693 \\
\hline Long-term loans & 122,755 & 165,326 & 210,688 & 251,276 & 288,058 \\
\hline Working capital loan & 7,009 & 9,319 & 10,198 & 13,087 & 13,584 \\
\hline Cash deficit loan & - & - & - & - & - \\
\hline Current liabilities & 80,047 & 79,895 & 81,166 & 82,519 & 84,998 \\
\hline Total liabilities & 278,003 & 360,254 & 445,027 & 537,405 & 618,512 \\
\hline
\end{tabular}

Note: $-=$ not available; FY = fiscal year; NPR = Nepalese rupee.

TABLE B.5: Projected Key Financial Ratios under the Reform Scenario

\begin{tabular}{|c|c|c|c|c|c|}
\hline Key financial ratios & FY2018 & FY2019 & FY2020 & FY2021 & FY2022 \\
\hline \multicolumn{6}{|l|}{ Profitability ratios } \\
\hline PBITDA margin (\%) & 24 & 44 & 39 & 44 & 35 \\
\hline Profit after tax margin (\%) & 6 & 19 & 15 & 20 & 13 \\
\hline Return on equity (\%) & 4 & 14 & 11 & 16 & 10 \\
\hline Return on net worth (\%) & 6 & 16 & 11 & 14 & 9 \\
\hline Return on gross fixed assets (\%) & 2 & 6 & 5 & 7 & 4 \\
\hline Return on net fixed assets (\%) & 3 & 8 & 6 & 8 & 5 \\
\hline Return on total assets (\%) & 2 & 7 & 5 & 8 & 5 \\
\hline \multicolumn{6}{|l|}{ Leverage ratios } \\
\hline Debt-to-equity ratio & 1.36 & 1.45 & 1.53 & 1.56 & 1.56 \\
\hline Debt-to-net worth ratio & 1.82 & 1.57 & 1.48 & 1.32 & 1.25 \\
\hline Debt service coverage ratio & 2.04 & 2.27 & 2.24 & 2.81 & 2.17 \\
\hline Interest service coverage ratio & 3.91 & 4.48 & 4.51 & 5.93 & 4.96 \\
\hline Self-financing ratio & 0.11 & 0.31 & 0.35 & 0.51 & 0.53 \\
\hline
\end{tabular}

Note: $F Y=$ fiscal year; PBITDA = profit before interest, taxes, depreciation, and amortization. 


\section{Appendix C: Investment Requirements under the Business as Usual Scenario}

\begin{tabular}{|c|c|c|c|c|c|c|}
\hline \multirow[b]{2}{*}{ Types of investment } & \multicolumn{5}{|c|}{ Average annual investments (\$ million) } & \multirow{2}{*}{$\begin{array}{l}\text { Total investment } \\
\text { financing needs } \\
\text { (\$ million) } \\
2018-40\end{array}$} \\
\hline & $\begin{array}{l}\text { Historical investments } \\
2010-17\end{array}$ & \multicolumn{4}{|c|}{ Forecast periods-Business as usual } & \\
\hline Hydro storage & - & 339 & 284 & 387 & 532 & 8,388 \\
\hline Hydro (ROR+PROR) & 372 & 237 & 340 & 465 & 638 & 8,875 \\
\hline Solar/wind & - & 69 & 67 & 90 & 148 & 1,945 \\
\hline T\&D & 156 & 343 & 378 & 517 & 709 & 10,421 \\
\hline Total & 527 & 980 & 1,042 & 1,424 & 1,955 & 28,965 \\
\hline Total (\% of GDP) & $2 \%$ & $2.7 \%$ & $2.3 \%$ & $2.5 \%$ & $2.7 \%$ & $2.0-2.7 \%$ \\
\hline
\end{tabular}

Assumptions used to estimate investment requirements from WECS demand projections

- Capacity factor: $50 \%$

- Reserve margin: $20 \%$

- T\&D loss: $15 \%$

- Hydro capex: US\$1.5 million per MW for ROR and PROR and US\$2.5 million per MW for storage hydro

- Solar capex: US\$1.0 million per MW

- Wind capex: US\$1.4 million per MW

- T\&D: $30 \%$ of total investment plan

Note: - = not available; capex = capital expenditure; GDP = gross domestic product; $\mathrm{MW}$ = megawatts;

$\mathrm{PROR}=$ peaking run-of-the-river; ROR = run-of-the-river; T\&D = transmission and distribution. 
(4) WORLD BANK GROUP 